\title{
Pyruvate secretion by oral streptococci modulates hydrogen peroxide dependent antagonism
}

\author{
Sylvio Redanz ${ }^{1} \cdot$ Puthayalai Treerat $^{1} \cdot$ Rong $\mathrm{Mu}^{1} \cdot$ Ulrike Redanz $^{1} \cdot$ Zhengzhong Zou $^{1} \cdot$ Dipankar Koley $^{2} \cdot$ \\ Justin Merritt $\mathbb{1}^{1,3} \cdot$ Jens Kreth $\mathbb{1}^{1,3}$
}

Received: 2 August 2019 / Revised: 14 January 2020 / Accepted: 16 January 2020 / Published online: 27 January 2020

(c) The Author(s), under exclusive licence to International Society for Microbial Ecology 2020

\begin{abstract}
Many commensal oral streptococci generate $\mathrm{H}_{2} \mathrm{O}_{2}$ via pyruvate oxidase ( $\mathrm{SpxB}$ ) to inhibit the growth of competing bacteria like Streptococcus mutans, a major cariogenic species. In Streptococcus sanguinis SK36 (SK36) and Streptococcus gordonii DL1 (DL1), spxB expression and $\mathrm{H}_{2} \mathrm{O}_{2}$ release are subject to carbon catabolite repression by the catabolite control protein A (CcpA). Surprisingly, ccpA deletion mutants of SK36 and DL1 fail to inhibit $S$. mutans despite their production of otherwise inhibitory levels of $\mathrm{H}_{2} \mathrm{O}_{2}$. Using $\mathrm{H}_{2} \mathrm{O}_{2}$-deficient $\operatorname{spxB}$ deletion mutants of SK36 and DL1, it was subsequently discovered that both strains confer protection in trans to other bacteria when $\mathrm{H}_{2} \mathrm{O}_{2}$ is added exogenously. This protective effect depends on the direct detoxification of $\mathrm{H}_{2} \mathrm{O}_{2}$ by the release of pyruvate. The pyruvate dependent protective effect is also present in other $s p x B$-encoding streptococci, such as the pneumococcus, but is missing from $s p x B$-negative species like $S$. mutans. Targeted and transposon-based mutagenesis revealed Nox (putative $\mathrm{H}_{2} \mathrm{O}$-forming NADH dehydrogenase) as an essential component required for pyruvate release and oxidative protection, while other genes such as sodA and $d p s$ play minor roles. Furthermore, pyruvate secretion is only detectable in aerobic growth conditions at biofilm-like cell densities and is

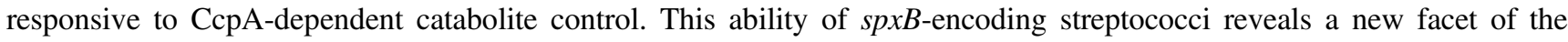
competitive interactions between oral commensals and pathobionts and provides a mechanistic basis for the variable levels of inhibitory potential observed among $\mathrm{H}_{2} \mathrm{O}_{2}$-producing strains of commensal oral streptococci.
\end{abstract}

\section{Introduction}

The oral cavity is a habitat for more than 700 different microbial taxa [1]. Oral microbes are exposed to saliva flow and nutrition intake causing mechanical removal, in addition to changing conditions in temperature, oxygen

Supplementary information The online version of this article (https:// doi.org/10.1038/s41396-020-0592-8) contains supplementary material, which is available to authorized users.

$\triangle$ Sylvio Redanz

sylvio.redanz@gmx.de

1 Department of Restorative Dentistry, Oregon Health \& Science University, Portland, OR 97239, USA

2 Department of Chemistry, Oregon State University, Corvallis, OR 97331, USA

3 Department of Molecular Microbiology and Immunology, School of Medicine, Oregon Health \& Science University, Portland, OR 97239, USA tension, and $\mathrm{pH}$ levels. To cope with the permanent environmental stresses oral bacteria are mostly organized in matrix enclosed communities called biofilms, which provide protection against all these factors [2]. Moreover, biofilm-dwelling oral microbes are in symbiosis with the host and provide protection against invading pathogens $[3,4]$. However, in case of an increasing biofilm volume and/or an alteration of the species composition to a dysbiotic state, these mixed species biofilms cause oral diseases like caries, chronic gingivitis, periodontitis, and others [5-7].

Streptococci are among the first colonizers of the oral hard tissue; they provide specific lectin-like attachment sides for later colonizers and are essential for initial biofilm formation [8]. In their role as initial colonizers, oral streptococci compete with other microorganisms by releasing significant amounts of hydrogen peroxide $\left(\mathrm{H}_{2} \mathrm{O}_{2}\right)$, which is generated by the pyruvate oxidase $\mathrm{SpxB}$ in an oxygen dependent manner [9-13]. The ability to release $\mathrm{H}_{2} \mathrm{O}_{2}$ as well as to deal with its toxicity influences the composition of the mature biofilm and is therefore of high relevance for 
the ecology of the mixed-species oral biofilm. Interestingly, despite many investigations into streptococcal reactive oxygen species stress mechanisms [14-17], it is still not fully understood how oral streptococci manage $\mathrm{H}_{2} \mathrm{O}_{2}$ stress, since they do not encode enzymes for direct detoxification of $\mathrm{H}_{2} \mathrm{O}_{2}$ (i.e., catalase) [17-19].

Streptococcus sanguinis SK36 (SK36) and S. gordonii DL1 (DL1) are abundant and well characterized oral commensals [8]. Their $\mathrm{H}_{2} \mathrm{O}_{2}$ dependent antagonism against caries associated $S$. mutans has been demonstrated $[12,13,20-23]$. In both species, the expression of $\operatorname{spxB}$ is under carbon catabolite control mediated by catabolite control protein A (CcpA) repression [24, 25]. As a result, $\mathrm{H}_{2} \mathrm{O}_{2}$ release and consequently its inhibitory capacity is influenced by different carbohydrates [24]. Interestingly, the CcpA dependent repression of $s p x B$ expression works differently in SK36 and DL1: while an increased glucose concentration causes a reduced release of $\mathrm{H}_{2} \mathrm{O}_{2}$ in DL1, there is almost no glucose effect on $\mathrm{H}_{2} \mathrm{O}_{2}$ release in SK36. Even under low-glucose concentrations, $s p x B$ is under strong CcpA dependent catabolite control. Under these conditions, $\mathrm{H}_{2} \mathrm{O}_{2}$ release is significantly increased in SK36 $\triangle c c p A$ but mostly unaffected in DL1 $\triangle c c p A$ compared with its parental wild-type strain [24, 25].

Accordingly, glucose concentration affects the inhibitory capacity of DL1, but exerts a minimal impact upon SK36 [11]. Recently, we made the surprising observation that cсpA mutants exhibit a dramatic reduction in their inhibitory capacities, despite producing inhibitory levels of $\mathrm{H}_{2} \mathrm{O}_{2}$. The present study aimed to elucidate the underlying mechanism of this intriguing phenotype. Here, we provide the first evidence demonstrating prokaryotic pyruvate secretion as a potent antioxidant for $\mathrm{H}_{2} \mathrm{O}_{2}$ production, which has potentially far reaching consequences for our understanding of the competitive interactions between members of the oral microbiome.

\section{Materials and methods}

\section{Bacterial strains and media}

All bacterial strains (Table S1) used in this study were grown in liquid or on agar solidified Bacto Brain Heart Infusion (BHI, Becton Dickinson \& Co., Sparks, MD, USA) at $37{ }^{\circ} \mathrm{C}$ under aerobic $\left(5 \% \mathrm{CO}_{2}\right)$ or anaerobic $\left(90 \% \mathrm{~N}_{2}, 5 \% \mathrm{CO}_{2}, 5 \% \mathrm{H}_{2}\right)$ conditions. Glucose was added to the media from a filter sterilized $20 \%$ (w/v) stock solution where indicated. The following antibiotics were supplemented for selection: kanamycin $\left(300 \mu \mathrm{g} \mathrm{ml}^{-1}\right)$, erythromycin $\left(10 \mu \mathrm{g} \mathrm{ml}^{-1}\right)$, and spectinomycin $\left(200 \mu \mathrm{g} \mathrm{ml}^{-1}\right)$.
Planktonic and high-cell-density growth conditions

The release of the protective component was tested under planktonic and high-cell-density growth conditions. Twenty milliliters of BHI was inoculated with $S$. sanguinis $\Delta c c p A /$ $\triangle \operatorname{spx} B$ cells from a fresh overnight culture (PBS washed) to a final $\mathrm{OD}_{600}=0.05$ and incubated aerobically $\left(37^{\circ} \mathrm{C}, 5 \%\right.$ $\mathrm{CO}_{2}$ ). After $2 \mathrm{~h}$ intervals, $200 \mu \mathrm{l}$ were applied on sterile membrane filters $(47 \mathrm{~mm}, 0.45-\mu \mathrm{m}$ pore size, Millipore) being placed on BHI plates and allowed to dry for $30 \mathrm{~min}$. Subsequently, filters were removed and the plates were stored at $4{ }^{\circ} \mathrm{C}$. For high-cell-density growth conditions (on agar solidified medium [26]), $200 \mu \mathrm{l}$ of $S$. sanguinis $\Delta c c p A /$ $\Delta s p x B$ cells from a fresh overnight culture (PBS washed, $\mathrm{OD}_{600}=0.5$ ) was applied to sterile membrane filters, placed on BHI plates, dried for $30 \mathrm{~min}$, and incubated aerobically $\left(37^{\circ} \mathrm{C}, 5 \% \mathrm{CO}_{2}\right)$. After $2 \mathrm{~h}$ intervals, filters were removed and the plates were stored at $4{ }^{\circ} \mathrm{C}$. The next day, $\mathrm{H}_{2} \mathrm{O}_{2}$ protection assays were performed as described below.

\section{DNA manipulations}

Standard nucleic acid recombinant protocols were use [27]. Gene deletions as well as complementation of the respective genes were performed via allelic replacement with previously described transformation protocols [28-31]. For a detailed description please refer to the Supplementary material section. Primers are listed in Table S2.

\section{Accession number(s)}

GenBank accession numbers for sequences determined by comC locus sequencing (Supplementary material) are as follows: MN257610 (S. oralis subsp. tigurinus J22, comC), MN257611 (S. infantis LZ2, comC), and MN257612 (S. mitis 12261, comC).

\section{Measurement of relative $\mathrm{H}_{2} \mathrm{O}_{2}$ production}

To detect and quantify $\mathrm{H}_{2} \mathrm{O}_{2}$, BHI/Prussian-blue indicator plates were prepared as previously described [32]. Cultivation and determination of relative $\mathrm{H}_{2} \mathrm{O}_{2}$ release was performed as described earlier [29, 33]. Briefly, overnightcultures of the investigated strains were washed with PBS and adjusted to an $\mathrm{OD}_{600}$ of 0.5 . Twelve microliters was applied to indicator plates and incubated overnight at $37^{\circ} \mathrm{C}$ under oxic conditions $\left(5 \% \mathrm{CO}_{2}\right) . \mathrm{H}_{2} \mathrm{O}_{2}$ release was determined by measuring the distance between the edge of the colony and the end of the Prussian blue precipitation zone. For each colony, arithmetic means were calculated from four measurements at different positions. At least two colonies were measured per experiment with the average 
A)

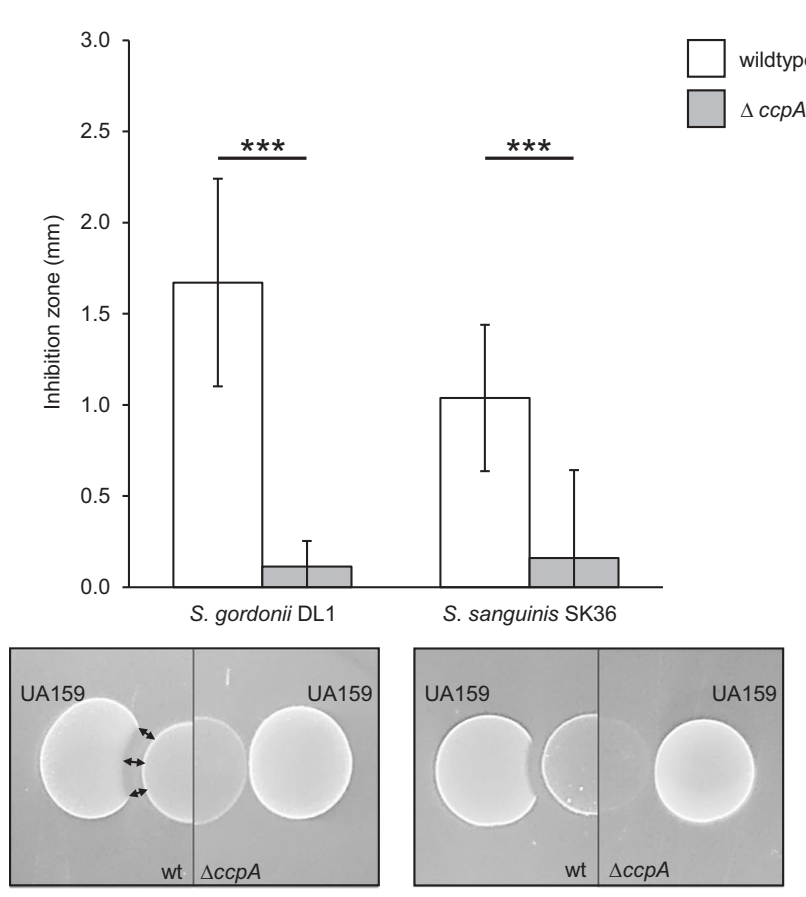

Fig. $1 \mathrm{H}_{2} \mathrm{O}_{2}$ release and growth inhibition characteristics of $S$. gordonii DL1 and $S$. sanguinis SK36 wild-type vs. $\operatorname{ccpA}$ deletion mutants. a Growth inhibition of $S$. mutans UA159 is displayed as the mean distance between the edge of the oral streptococci colony and the $S$. mutans colony. Below the graph, representative pictures of the inhibitory effect are shown. b $\mathrm{H}_{2} \mathrm{O}_{2}$ production is shown as relative $\mathrm{H}_{2} \mathrm{O}_{2}$ release of cells grown aerobically on Prussian blue $\mathrm{H}_{2} \mathrm{O}_{2}$

serving as a single data-point. Each experiment was repeated four times.

\section{Growth inhibition assay}

Deferred antagonism assays were performed following an earlier study [12]. Briefly, BHI plates were inoculated with $12 \mu \mathrm{l}$ of washed cells (PBS, $\mathrm{OD}_{600}=0.5$ ) and incubated for $24 \mathrm{~h}$ at $37^{\circ} \mathrm{C}\left(5 \% \mathrm{CO}_{2}\right)$. Subsequently, $12 \mu \mathrm{l}$ of a similarly prepared $S$. mutans culture was spotted in close proximity followed by $24 \mathrm{~h}$ of incubation at $37^{\circ} \mathrm{C}$. Inhibition zones were measured at three different positions and averaged for each colony (indicated in Fig. 1a). Arithmetic means of at least two colonies served as a single data-point. Each experiment was repeated at least three times.

\section{$\mathrm{H}_{2} \mathrm{O}_{2}$ protection assay}

The $\mathrm{H}_{2} \mathrm{O}_{2}$ oxidative protection assay was performed as follows: BHI plates were inoculated with $12 \mu$ of washed cells from overnight-cultures (PBS, $\left.\mathrm{OD}_{600}=0.5\right)$ and incubated for $24 \mathrm{~h}$ at $37^{\circ} \mathrm{C}\left(5 \% \mathrm{CO}_{2}\right)$. The next day, an overnight-culture of the indicator species ( $S$. mutans $/ S$. epidermidis/E. coli) was washed and adjusted to an $\mathrm{OD}_{600}$
B)

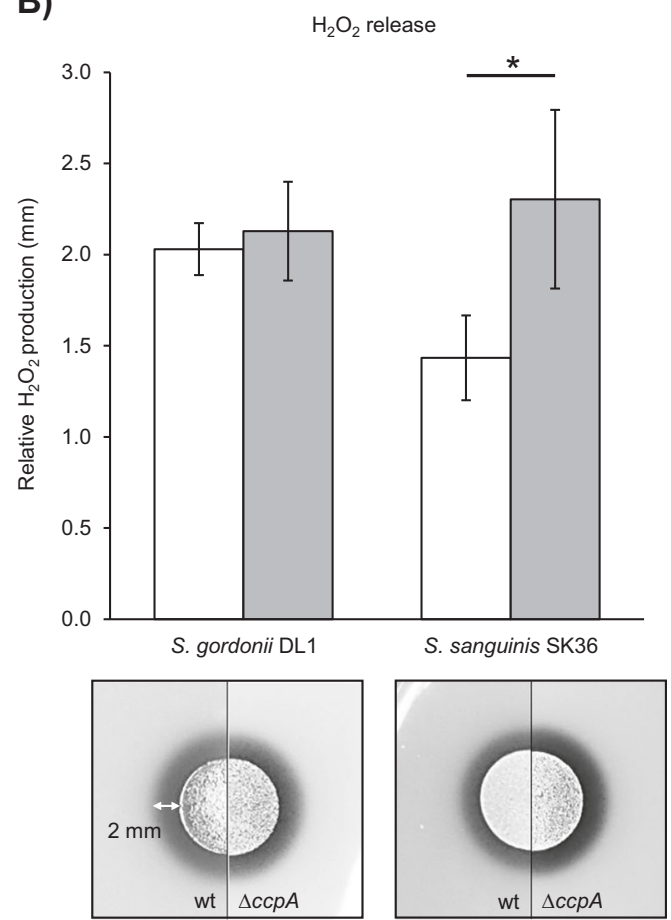

indicator plates, as previously described [33]. Below the graph, representative colonies are displayed forming a blue halo on Prussian blue indicator plates. Averages, standard deviations, and representative images are derived from at least three independent experiments. Significance levels: $* p<0.05 ; * * * p<0.001$ ( $t$-test, two-tailed, and unpaired).

of 0.5. Four milliliters of molten BHI-soft-agar (0.6\% agar, $60{ }^{\circ} \mathrm{C}$ ) was thoroughly mixed with $200 \mu \mathrm{l}$ of the indicator species cell suspension and immediately poured onto the agar plate. Plates were kept at room temperature for $30 \mathrm{~min}$ to allow the soft agar layer to solidify. Subsequently, a filter disc (cotton fiber, $0.84 \mathrm{~mm} \times 7.3 \mathrm{~mm}$ diameter, Thick Blot Filter Paper, Bio-Rad) containing $\mathrm{H}_{2} \mathrm{O}_{2}$ was added in close proximity to the colony of the test strain followed by $24 \mathrm{~h}$ of incubation at $37^{\circ} \mathrm{C}$. Inhibition zones were measured at three different positions and averaged to serve as a single datapoint. Each experiment was repeated at least three times. A schematic description is given in the Supplementary material section (Fig. S1).

\section{Transposon mutagenesis and screening}

The MarC9/magelan6-based in vitro transposition system was utilized to generate random mutations in $S$. sanguinis $\Delta s p x B$ as previously described [34]. All resulting transformants were screened by a modified $\mathrm{H}_{2} \mathrm{O}_{2}$ protection assay under the following assumptions: (i) the protective effect guards the $\mathrm{H}_{2} \mathrm{O}_{2}$ challenged indicator strain, leading to visible growth of indicator strain colonies; (ii) mutation of a gene related to the protective effect results in a reduced 
protective effect; and (iii) the $\mathrm{H}_{2} \mathrm{O}_{2}$ challenged indicator strain exhibits reduced or no growth. All candidates resulting in a reduced growth of the $\mathrm{H}_{2} \mathrm{O}_{2}$ challenged indicator strain were verified by an additional $\mathrm{H}_{2} \mathrm{O}_{2}$ protection assay. Affected genes were identified by a modified SiteFinding-PCR as described elsewhere [35]. For a detailed description of the screening process and SiteFinding-PCR protocol please refer to the respective Supplementary material section.

\section{Extraction of the protective substance from solidified BHI}

For the characterization and identification of the protective component, raw extracts were obtained as followed: a sterile filter membrane ( $47 \mathrm{~mm}, 0.45-\mu \mathrm{m}$ pore size, Millipore) was placed on a BHI agar plate. A fresh overnight culture of each respective strain was washed (PBS) and adjusted to an $\mathrm{OD}_{600}=0.5$. One hundred and fifty microliters was applied to the membrane, allowed to dry, and incubated aerobically for $24 \mathrm{~h}$ at $37^{\circ} \mathrm{C}$ (or otherwise stated). The membrane was then removed and the underlying agar was cut out, placed into a $10 \mathrm{ml}$ syringe, and pressed through a sterile filter $(0.2 \mu \mathrm{m}$ cellulose acetate membrane, VWR). Liquid extracts were stored at $4{ }^{\circ} \mathrm{C}$ or tested immediately.

\section{$\mathrm{H}_{2} \mathrm{O}_{2}$ depletion assay}

Twenty five microliters of the liquid extracts described above were mixed 1:1 with the same volume of various concentrations of $\mathrm{H}_{2} \mathrm{O}_{2}$ and incubated for $30 \mathrm{~min}$ at room temperature. Forty microliters of the mixture was applied to a filter disc (cotton fiber, $0.84 \mathrm{~mm} \times 7.3 \mathrm{~mm}$ diameter, Thick Blot Filter Paper, Biorad) and placed on a BHI/Prussian blue indicator plate for visualization of the remaining $\mathrm{H}_{2} \mathrm{O}_{2}$. Alternatively, $\mathrm{H}_{2} \mathrm{O}_{2}$ concentrations were determined with the Amplex Red Peroxide/Peroxidase Assay (Invitrogen) following manufacturer's instructions.

\section{Chemical characterization and identification of the protective compound}

Extracts of SK36 $\Delta s p x B / \Delta c c p A$ were collected from solidified BHI as described above and either incubated at $100{ }^{\circ} \mathrm{C}(30 \mathrm{~min})$, treated with protease (alkaline protease, Promega), lipase (5\%, MP Biomedicals), ultrafiltered with a weight cutoff of $1 \mathrm{kDa}$ (Macrosep, Pall Corporation), or mixed with chloroform as described below. Subsequently, the $\mathrm{H}_{2} \mathrm{O}_{2}$ depleting activity was tested as described above $\left(\mathrm{H}_{2} \mathrm{O}_{2}\right.$ depletion assay).

For chemical identification, $400 \mu \mathrm{l}$ of extracts was mixed with chloroform by adding an equal volume followed by vigorous shaking (Bertin Precellys homogenizer, $5 \mathrm{~min}$,
$5000 \mathrm{rpm})$. Phases were separated by centrifugation $\left(21,000 \times g, 15 \mathrm{~min}, 4^{\circ} \mathrm{C}\right)$. The aqueous phase, containing the active substance, was then analyzed by liquid chromatography-information-dependent acquisition-mass spectrometry (LC-IDA-MS; Oregon State University Mass Spectrometry, Corvallis, OR, USA) using the IROA library of metabolite standards (IROA Technologies, Bolton, MA, USA).

\section{Enzymatic elimination of pyruvate and testing of $\mathrm{H}_{2} \mathrm{O}_{2}$ depletion activity}

Pyruvate was depleted from extracts following a previously published procedure [36] with modifications by the addition of pyruvate oxidase (PoxB, MP Biomedicals). The reaction leads to the formation of acetate and $\mathrm{H}_{2} \mathrm{O}_{2}$, which was subsequently eliminated by the addition of catalase. Catalase was subsequently heat-inactivated.

The elimination of pyruvate resulted in a 1:5 dilution of the extracts. Thus, for $\mathrm{H}_{2} \mathrm{O}_{2}$ depletion activity testing, untreated extracts were diluted accordingly. Treated and untreated extract solutions were mixed with an equal amount of $\mathrm{H}_{2} \mathrm{O}_{2}$ ( $2 \mathrm{mM}$ ) and incubated at room temperature for $30 \mathrm{~min}$. Subsequently, $\mathrm{H}_{2} \mathrm{O}_{2}$, pyruvate, and acetate concentrations were determined with the Amplex Red Peroxide/Peroxidase Assay (Invitrogen), EnzyChrom Pyruvate Assay (BioAssays Systems), and EnzyChrom Acetate Assay (BioAssays Systems) respectively, following the manufacturer's instructions. For a detailed description of the procedure, please refer to the Supplementary material section.

\section{Results}

\section{SK36 and DL1 excrete an antioxidant substance}

While working with $S$. gordonii DL1 $\triangle c c p A$ and $S$. sanguinis SK36 $\Delta c c p A$ mutants, we were surprised to discover that these strains lose their antagonistic abilities against $S$. mutans (Fig. 1a), despite producing significant amounts of inhibitory $\mathrm{H}_{2} \mathrm{O}_{2}$ (Fig. 1b). We previously demonstrated that the deletion of $\operatorname{spxB}$ in $S$. sanguinis and $S$. gordonii as well as the addition of catalase to the wild-type strains abolished any inhibitory effect on $S$. mutans, which verified that no other inhibitory component is secreted under the tested conditions [20].

To test the hypothesis that the diminished inhibition of $S$. mutans by the $c с p A$ mutants is due to the potential secretion of a protective compound, we developed a new antagonism assay (Fig. S1). Initially a set of clinical Staphylococcus isolates and $S$. mutans were evaluated for their suitability as indicator strains. S. epidermidis $\mathrm{F}$ was chosen for being the most $\mathrm{H}_{2} \mathrm{O}_{2}$ susceptible strain (Fig. S2). A dose-dependent 
A)

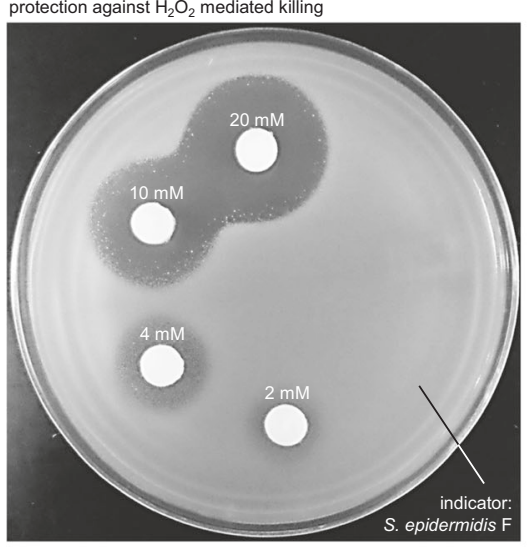

B)

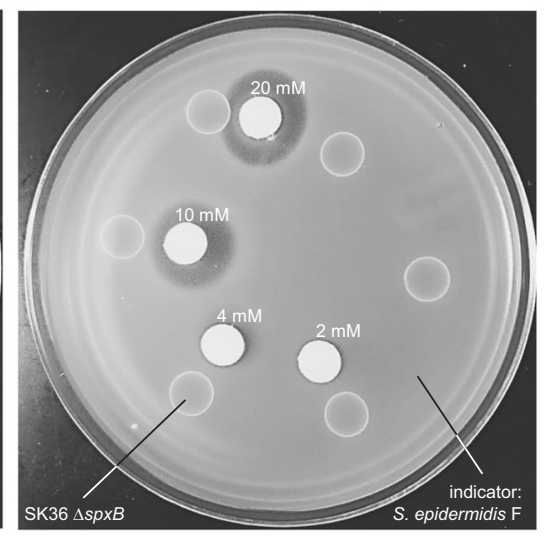

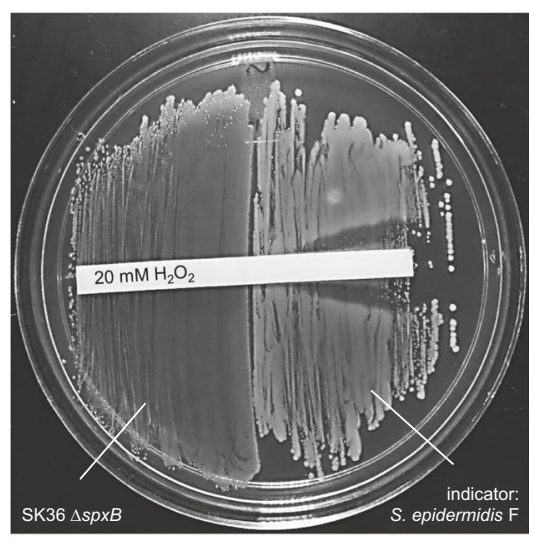

C)
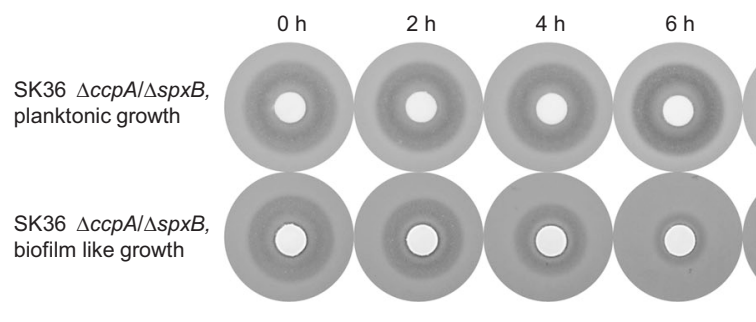

Fig. 2 S. sanguinis $\Delta s p x B$ protects against $\mathrm{H}_{2} \mathrm{O}_{2}$ mediated killing. a A representative $\mathrm{H}_{2} \mathrm{O}_{2}$ protection assay is shown. SK36 was grown on BHI agar plates, overlaid with soft agar containing $S$. epidermidis $\mathrm{F}$ (indicator strain), and challenged with different concentrations of $\mathrm{H}_{2} \mathrm{O}_{2}$ delivered by previously soaked filter discs. The left panel shows the respective control plate without $S$. sanguinis. b $S$. sanguinis $\Delta$ spxB was grown on BHI agar. Subsequently, the indicator strain was inoculated in close proximity to SK36 $\Delta s p x B$ and challenged by an $\mathrm{H}_{2} \mathrm{O}_{2}$-soaked filter strip. The concentrations of $\mathrm{H}_{2} \mathrm{O}_{2}$ are indicated. c The appearance of the protective effect was tested with SK36 $\Delta$ spxB/
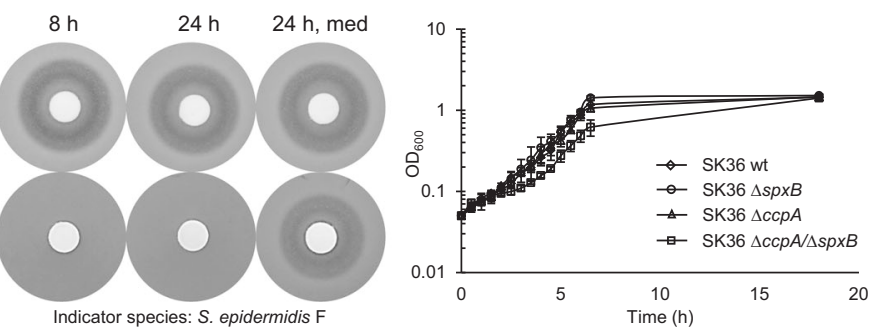

$\triangle c c p A$ under planktonic and high-cell-density conditions over a time course. Upper panel: $200 \mu \mathrm{l}$ of supernatant derived from a liquid culture was sterile filtered at the indicated time points and added to BHI plates. Lower panel: bacteria were applied to sterile filters and then placed onto BHI plates. At the indicated time points, the filters containing the bacteria were removed from the plates. Afterward, the plates were overlaid with soft agar containing $S$. epidermidis $\mathrm{F}$ and then challenged with $\mathrm{H}_{2} \mathrm{O}_{2}$-soaked filter discs. Presented is also the planktonic growth monitored by optical density. SK36 wt, spxB, and cсpA single mutants serve as reference.

inhibition was observed when filter disks infused with different $\mathrm{H}_{2} \mathrm{O}_{2}$ concentrations ranging from 2 to $20 \mathrm{mM}$ were placed on a soft agar plate containing $S$. epidermidis $\mathrm{F}$ (Fig. 2a, left). However, when SK36 $\Delta \operatorname{spxB}$ was inoculated on the plate first, the observed inhibition of $S$. epidermidis was reduced, especially near the border closest to SK36 $\Delta s p x B$ (Fig. 2a, right). This observation could be repeated when both $S$. epidermidis F and SK36 $\Delta s p x B$ were inoculated next to each other and a filter-strip with $200 \mu \mathrm{l}$ $\mathrm{H}_{2} \mathrm{O}_{2}(20 \mathrm{mM})$ was placed over the strains. Inhibition of $S$. epidermidis by $\mathrm{H}_{2} \mathrm{O}_{2}$ could only be observed at the distal side, but not at the proximal side where both strains came into close contact. This observation points to the existence of a diffusible protective component, which prevents or reduces the effectiveness of $\mathrm{H}_{2} \mathrm{O}_{2}$ mediated killing (Fig. 2b). Exemplarily, wild-type strains and the isogenic ccpA mutants of $S$. sanguinis SK36 and S. gordonii DL1 are shown in Supplementary Fig. S3. Due to the autologous release of $\mathrm{H}_{2} \mathrm{O}_{2}$ in these strains, the protective effect is mostly masked. Notably, slight differences in the inhibition zone are visible comparing wild-type and $c c p A$ mutants.

\section{High-cell-density conditions promote the protective effect}

The capacity of supernatants of planktonically grown SK36 $\Delta c c p A / \Delta s p x B$ as well as cells grown under high-celldensity conditions on BHI plates were tested in $\mathrm{H}_{2} \mathrm{O}_{2}$ protection assays. Supernatants of planktonic cells demonstrated no protective capacity, while cells grown on BHI agar plates (representing high-density growth conditions similar to biofilms [26]) released significant amounts of the protective substance into the surrounding media within $4 \mathrm{~h}$ of incubation (Fig. 2c). Thus, the protective effect seems to be relevant under high-cell-density conditions of SK36.

\section{Protection against $\mathrm{H}_{2} \mathrm{O}_{2}$ mediated killing is CcpA dependent}

Considering the discrepancy between the relatively high amount of released $\mathrm{H}_{2} \mathrm{O}_{2}$ and the weak antagonistic ability of $S$. sanguinis SK36 $\Delta c c p A$ and $S$. gordonii DL1 $\Delta c c p A$ (Fig. 1), it was hypothesized that $\mathrm{H}_{2} \mathrm{O}_{2}$ protection might be 
A)

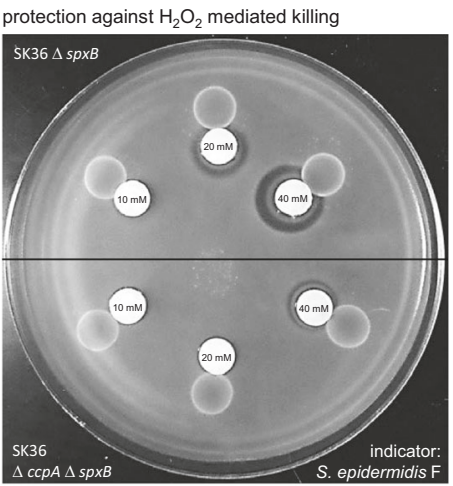

B)

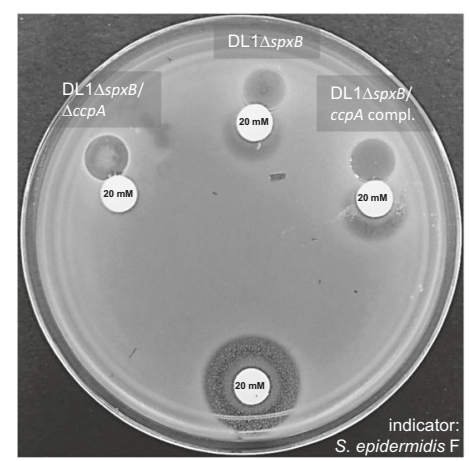

Fig. 3 CcpA dependency of the protective effect. a A representative plate is shown to illustrate the differences in inhibition zones caused by various concentrations of $\mathrm{H}_{2} \mathrm{O}_{2}$ in close proximity to the SK36 spxB

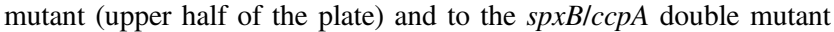
(lower half of the plate). b A representative plate of DL1 is shown demonstrating the differences in the protective capacities of the spxB mutant, the $s p x B / c c p A$ double mutant, and the $c c p A$ complemented strain, which exhibits the same protective capacity as the spxB single mutant. An additional $\mathrm{H}_{2} \mathrm{O}_{2}$ filter disc was placed on the opposite side of the plate to serve as a control. c SK36 wt, $\operatorname{spx} B$ mutant, $c c p A / s p x B$ double mutant, and the $c c p A$ complemented strain were analyzed in a $\mathrm{H}_{2} \mathrm{O}_{2}$ protection assay. The indicator strains were challenged with different concentrations of $\mathrm{H}_{2} \mathrm{O}_{2}$ (S. epidermidis-20 mM; E. coli$100 \mathrm{mM}$; S. mutans-100 mM). The averages and standard deviations of at least five independent experiments are displayed. Significance levels: $* p<0.05 ; * * p<0.01 ; * * * p<0.001$ ( $t$-test, two-tailed, and unpaired).

$2 \%$ glucose $(p<0.01)$. Thus, in $\mathrm{CcpA}^{+}$strains, the protective effect is reduced due to the presence of higher glucose concentrations, consistent with CcpA-dependent catabolite repression. In the $s p x B / c c p A$ double mutants, glucose concentration had no impact on $\mathrm{H}_{2} \mathrm{O}_{2}$ protection (Fig. 4a).

\section{Oxygen is essential for $\mathrm{H}_{2} \mathrm{O}_{2}$ protection}

In the wild-type background of SK36 and DL1, growthinhibiting amounts of $\mathrm{H}_{2} \mathrm{O}_{2}$ are only produced (and thus released) in the presence of oxygen [13]. $\mathrm{H}_{2} \mathrm{O}_{2}$ protection assays revealed, that the protective effect similarly responds to oxygen availability. Comparing aerobic and anaerobic growth conditions, $\mathrm{H}_{2} \mathrm{O}_{2}$ inhibition zones were significantly increased on anaerobically incubated plates compared with their aerobic counterparts. Thus, oxygen is essential for the appearance of the protective effect. Furthermore, no differences could be detected in anoxic conditions between the spxB and spxB/ccpA mutants of SK36 and DL1 (Fig. 4b, c). 


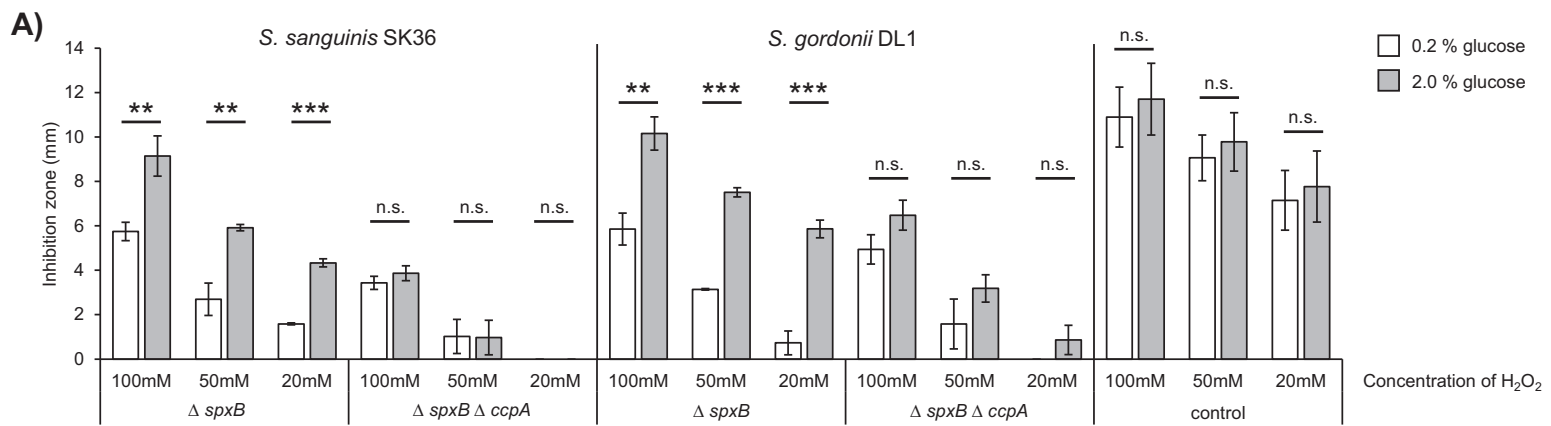

B)

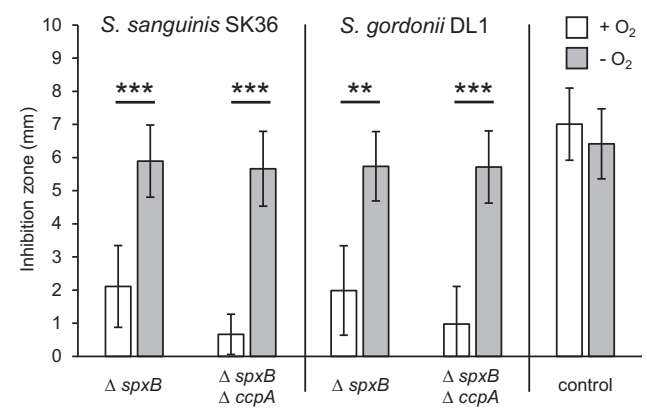

Fig. 4 Glucose and oxygen dependency of the protective effect. SK36 and DL1 wt, spxB mutants, and ccpA/spxB double mutants were analyzed in $\mathrm{H}_{2} \mathrm{O}_{2}$ protection assays. a The assay was performed on BHI agar with different glucose concentrations ( $2 \%$ and $0.2 \%)$. The indicator species was challenged with different concentrations of $\mathrm{H}_{2} \mathrm{O}_{2}$ (as displayed). An additional $\mathrm{H}_{2} \mathrm{O}_{2}$ filter disc was placed on the opposite side of the plate to serve as a control. b $\mathrm{H}_{2} \mathrm{O}_{2}$ protection

Thus, the absence of oxygen renders SK36 and DL1 unable to produce the protective effect, irrespective of CcpA function.

\section{SK36 eliminates $\mathrm{H}_{2} \mathrm{O}_{2}$ by releasing a protective component}

Cell-free extracts from BHI agar inoculated with SK36 ccpA/spxB and from sterile BHI agar (serving as control) were co-incubated with different amounts of $\mathrm{H}_{2} \mathrm{O}_{2}$ in a $\mathrm{H}_{2} \mathrm{O}_{2}$ depletion assay. In the presence of the extract, final $\mathrm{H}_{2} \mathrm{O}_{2}$ concentrations decreased from $10 \mathrm{mM}$ to $2.38 \mathrm{mM}$ $( \pm 0.45 \mathrm{mM})$. With an initial concentration of $1 \mathrm{mM}, \mathrm{H}_{2} \mathrm{O}_{2}$ levels dropped below the detection limit of $26 \mathrm{nM}$ (Fig. 5a). Comparable results were also observed on Prussian blue indicator plates (Fig. 5b). Blue halos, which indicate the presence of $\mathrm{H}_{2} \mathrm{O}_{2}$ in a concentration dependent manner, were considerably reduced in size in the presence of extract compared with the control. In both assays, the final $\mathrm{H}_{2} \mathrm{O}_{2}$ concentrations were significantly decreased when incubated with extracts, indicating the protective effect likely depends upon the direct elimination of $\mathrm{H}_{2} \mathrm{O}_{2}$, rather than through an oxidative stress response induced in the indicator organisms. assays were performed in the presence or absence of oxygen $(20 \mathrm{mM}$ $\mathrm{H}_{2} \mathrm{O}_{2}$ ). The averages and standard deviations of at least three independent experiments are shown. Significance levels: $* * p<0.01$; ${ }^{* * *} p<0.001$ ( $t$-test, two-tailed, unpaired). c Representative plates are shown to illustrate the different sizes of the inhibition zones in close proximity to the indicated strains \pm oxygen.

\section{Identification of genes related to the protective phenotype}

Initially, genes with a known connections to oxidative or $\mathrm{H}_{2} \mathrm{O}_{2}$ specific stress resistances were deleted, including gshAB (SSA_2186, glutathione biosynthesis bifunctional protein) [37-39], dps (SSA_0644, DNA-binding ferritinlike protein, oxidative damage protectant) $[14,17,40]$, sodA (SSA_0721, Mn/Fe-dependent superoxide dismutase) $[14,17]$, and the peroxide stress response transcriptional regulator fur (SSA_0686, perR analog, $\mathrm{Fe}^{2+} / \mathrm{Zn}^{2+}$ uptake regulation protein) $[14,40]$. All mutants were tested in the $\mathrm{H}_{2} \mathrm{O}_{2}$ protection assay described above. Of these, only the dps mutant exhibited a significant increase in the $\mathrm{H}_{2} \mathrm{O}_{2}$ inhibition zone (i.e., decreased protection) for both SK36 $\Delta s p x B$ and SK36 $\Delta s p x B / \Delta c c p A$ (Fig. 6a, b). The deletion of sodA modestly reduced the protective affect for SK36 $\Delta s p x B$, but did not affect the $\Delta s p x B / \Delta c c p A$ mutant.

Since the CcpA dependency of the protective phenotype could be demonstrated, numerous CcpA regulated genes were targeted. Forty genes from 19 operons were deleted due to their predicted regulation by $\mathrm{CcpA}$ in the RegPrecise database [41]. In addition, 24 neighboring genes were targeted, since they potentially share the respective 
A)

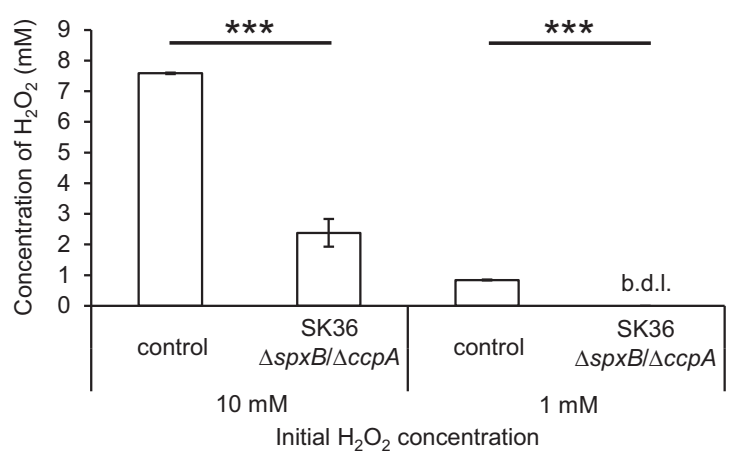

Fig. 5 Elimination of $\mathrm{H}_{2} \mathrm{O}_{2}$. Conditioned medium extracts of the SK36 ccpA/spxB double mutant as well as a BHI growth medium control were mixed 1:1 with various $\mathrm{H}_{2} \mathrm{O}_{2}$ solutions and incubated at room temperature for $30 \mathrm{~min}$. The estimated final concentrations of $\mathrm{H}_{2} \mathrm{O}_{2}$ are indicated. a $\mathrm{H}_{2} \mathrm{O}_{2}$ concentrations were determined with the Amplex Red Peroxide/Peroxidase Assay. The averages and standard

palindromic CcpA recognition site (cre, catabolite responsive element) or are potentially co-transcribed with respective CcpA regulated genes. Among these mutants (given in Table S3; Supplementary material section), only the nox mutation (SSA_1127, putative $\mathrm{H}_{2} \mathrm{O}$-forming NADH dehydrogenase) caused an obvious defect in $\mathrm{H}_{2} \mathrm{O}_{2}$ protection (Fig. 6a, b).

In addition, random transposon mutagenesis was performed to identify additional genes required for $\mathrm{H}_{2} \mathrm{O}_{2}$ protection. In total 6445 colonies were screened by a two-step $\mathrm{H}_{2} \mathrm{O}_{2}$ protection assay (see Supplementary materials). Eighteen mutants were identified showing a significantly increased inhibition zone compared with the parental strain. The genes SSA_1938 to SSA_1940 (fatty acid biosynthesis operon) were not considered further due to an obvious growth defect as previously described [42]. The most prominent $\mathrm{H}_{2} \mathrm{O}_{2}$ protection defect was caused by an insertion into nox (SSA_1127). Besides nox, dps was also identified by the transposon mutagenesis screen. However, the transposon insertion was located in the $d p s$ promoter, which might explain its relatively weak effect compared with the $d p s$ deletion mutant (Table S4, Fig. S4; Supplementary material section).

\section{Confirmation of the impact of nox on the protective effect}

BHI agar extracts derived from SK36 $\Delta s p x B / \Delta c c p A$, SK36 $\Delta d p s / \Delta s p x B / \Delta c c p A$, SK36 $\Delta g s h A B / \Delta s p x B / \Delta c c p A$, SK36 $\Delta \operatorname{sod} A / \Delta s p x B / \Delta c c p A$, and SK36 $\Delta n o x / \Delta s p x B / \Delta c c p A$ as well as from plain BHI agar plates (control) were tested via the $\mathrm{H}_{2} \mathrm{O}_{2}$ depletion assay. A positive reaction on Prussian blue agar plates (i.e., $\mathrm{H}_{2} \mathrm{O}_{2}$ ) occurred only around the
B)

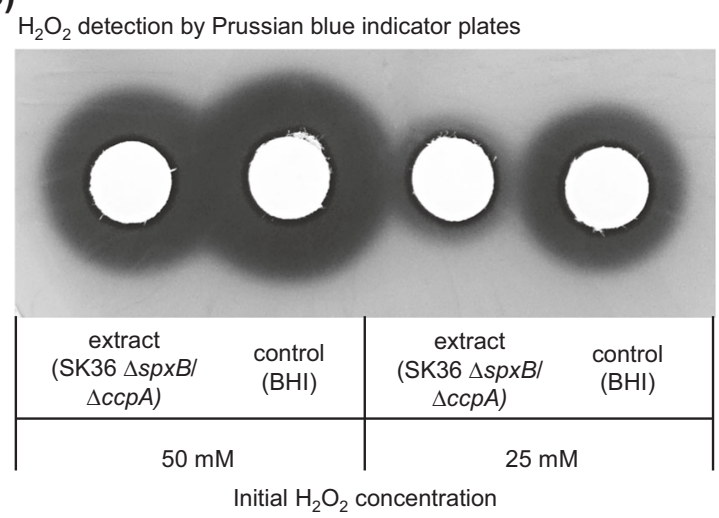

deviations are shown from three independent experiments. b Filter discs were soaked with $\mathrm{H}_{2} \mathrm{O}_{2}$ and placed on Prussian blue indicator plates. The sizes of the resulting halos are proportional to the amounts of $\mathrm{H}_{2} \mathrm{O}_{2}$. Representative images are shown. b.d.l. below detection limit.

filter discs soaked with the $\mathrm{H}_{2} \mathrm{O}_{2}$ /extract-mix derived from the control and SK36 $\Delta$ nox/ $\Delta s p x B / \Delta c c p A$ (Fig. 6c). No Prussian blue reaction was detectable around the other discs, indicating that the other mutants were still capable of eliminating $\mathrm{H}_{2} \mathrm{O}_{2}$ from the mixture. As an independent verification, final concentrations of $\mathrm{H}_{2} \mathrm{O}_{2}$ (initial concentration: $1 \mathrm{mM}$ ) were enzymatically determined in the $\mathrm{H}_{2} \mathrm{O}_{2}$ depletion assay. Only the extract of SK36 $\Delta$ nox $\Delta s p x B / \Delta c c p A$ and the control failed to eliminate $\mathrm{H}_{2} \mathrm{O}_{2}$ from the mixture. All other strains were able to deplete $\mathrm{H}_{2} \mathrm{O}_{2}$ with final concentrations falling below the $26 \mathrm{nM}$ detection limit (Fig. 6d).

\section{Identification and evaluation of pyruvate as the source of $\mathrm{H}_{2} \mathrm{O}_{2}$ protection}

The extract of SK36 $\Delta s p x B / \Delta c c p A$ is able to confer protection against $\mathrm{H}_{2} \mathrm{O}_{2}$ after lipase, protease, and heat treatment (data not shown). Furthermore, $\mathrm{H}_{2} \mathrm{O}_{2}$ protection activity was demonstrated for the aqueous phase after chloroform extraction and ultrafiltration ( $1 \mathrm{kDa}$ cutoff), suggesting a water soluble small molecule. Therefore, mass spectrometry-based metabolite profiling was performed on extracts derived from the following mutants: SK36 $\Delta s p x B$ (containing the protective component), SK36 $\Delta s p x B / \Delta c c p A$ (increased production of the protective component), and SK36 $\Delta$ spxB/ $\Delta c c p A / \Delta$ nox (lacking the protective component). Of the metabolites detected, only pyruvate matched the expected abundances for each of the mutants (Fig. 7a). The concentrations of pyruvate were also determined enzymatically and mirrored the mass spectrometry results (Fig. 7b). In addition, almost no pyruvate was detected in the anaerobic control (Fig. 7b). This agrees with the oxygen 


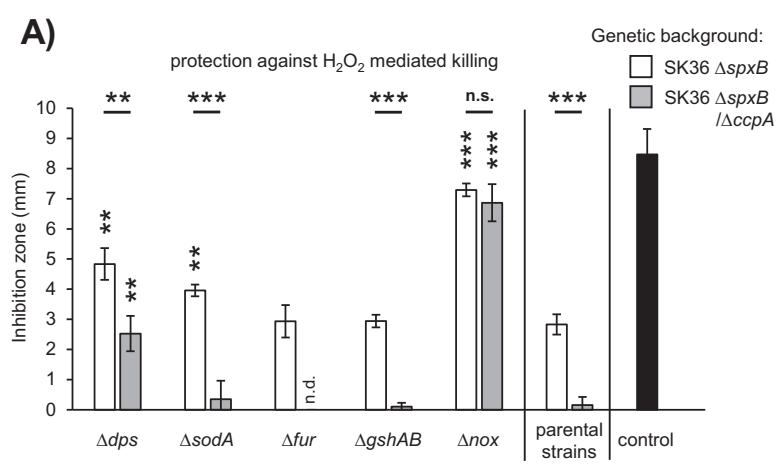

C)

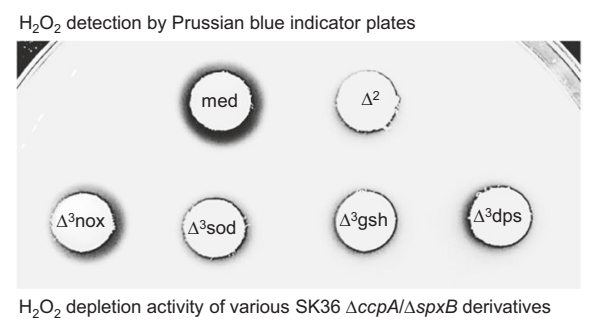

Fig. 6 Genes related to the protective effect. $\mathrm{H}_{2} \mathrm{O}_{2}$ protection assays were performed with the indicated mutants and controls. a Mutations of $d p s$, sodA, fur, gsh $A B$, and nox were tested in the SK36 $\Delta$ spxB background, while dps, sodA, gshAB, and nox mutations were assayed in the SK36 $\Delta c c p A / \Delta s p x B$ background. Paired $t$-tests were performed for each mutant relative to its parental stain. The respective significance levels are indicated by asterisks above each column. Significance levels between mutants of a respective gene in the SK36 $\Delta$ spxB and SK36 $\Delta c c p A / \Delta s p x B$ backgrounds were tested with unpaired $t$-tests and are indicated above each pair of columns. b Representative examples of the inhibition zones for each tested mutant are presented. c, $\mathbf{d}$ Conditioned medium extracts of the SK36 ccpA/spxB double mutant, its derivatives (as indicated), and $\mathrm{BHI}$ (control) were tested in an $\mathrm{H}_{2} \mathrm{O}_{2}$

dependency of the protective effect (Fig. 4b, c). As further evidence, pyruvate was depleted from SK36 $\Delta s p x B / \Delta c c p A$ extracts using the PoxB enzyme, resulting in a total loss of $\mathrm{H}_{2} \mathrm{O}_{2}$ depleting activity (Fig. 7c). The concentrations of pyruvate and $\mathrm{H}_{2} \mathrm{O}_{2}$ also decreased in a stoichiometric manner. The initial pyruvate concentration in the extracts decreased from $3.31 \mathrm{mM}( \pm 0.22 \mathrm{mM})$ before $\mathrm{H}_{2} \mathrm{O}_{2}$ treatment to $1.56 \mathrm{mM}( \pm 0.43 \mathrm{mM})$ after treatment (i.e., $1.75 \mathrm{mM}$ reduction). The decrease in pyruvate concentration corresponds precisely to the measured initial concentration of $\mathrm{H}_{2} \mathrm{O}_{2}(1.75 \pm 0.07 \mathrm{mM})$. In addition we determined the concentration of acetate, the corresponding end product of the reaction of pyruvate and $\mathrm{H}_{2} \mathrm{O}_{2}$. Its concentration increased from $1.28 \mathrm{mM}( \pm 0.63 \mathrm{mM})$ before $\mathrm{H}_{2} \mathrm{O}_{2}$ treatment to $3.01 \mathrm{mM}( \pm 0.91 \mathrm{mM})$ after treatment. This increase also mimics the concentration of the initial $\mathrm{H}_{2} \mathrm{O}_{2}$ concentration. The concentration of acetate after pyruvate depletion corresponds approximately to the sum of initial acetate and pyruvate concentration. $\mathrm{H}_{2} \mathrm{O}_{2}$ concentrations were largely unaffected by treatment with pyruvate depleted extracts,
B)

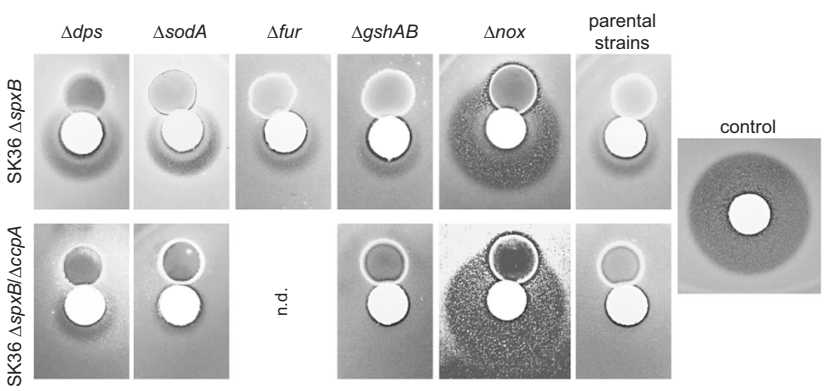

D)

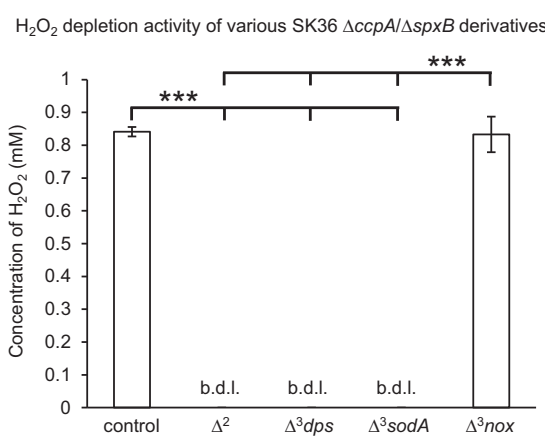

depletion assay. Initial $\mathrm{H}_{2} \mathrm{O}_{2}$ concentrations were $20 \mathrm{mM}$ (c) and $1 \mathrm{mM}$ (d). c Filter discs were soaked with the extract/ $/ \mathrm{H}_{2} \mathrm{O}_{2}$ mixture and placed on Prussian-blue-indicator plates. The sizes of the resulting halos are proportional to the amount of $\mathrm{H}_{2} \mathrm{O}_{2}$ present. A representative image is shown. d $\mathrm{H}_{2} \mathrm{O}_{2}$ concentrations were determined with the Amplex Red Peroxide/Peroxidase Assay. Averages and standard deviations from at least three independent experiments are presented. Significance levels: $* * p<0.01 ; * * * p<0.001$; n.d. not determined, n.s. not significant, b.d.1. below detection limit, med medium control, $\Delta^{2}-\mathrm{SK} 36 \Delta c c p A / \Delta s p x B$, $\Delta^{3}$ nox-SK36 $\Delta c c p A / \Delta s p x B / \Delta$ nox,$\Delta^{3}$ sod-SK36 $\Delta c c p A / \Delta s p x B /$ $\Delta \operatorname{sod} A, \Delta^{3} \mathrm{gsh}-\mathrm{SK} 36 \Delta c c p A / \Delta \operatorname{spx} B / \Delta g s h A B, \Delta^{3} \mathrm{dps}-\mathrm{SK} 36 \Delta c c p A /$ $\Delta \operatorname{spx} B / \Delta d p s$.

which resulted in a final $\mathrm{H}_{2} \mathrm{O}_{2}$ concentration of $1.66 \mathrm{mM}$ $( \pm 0.09 \mathrm{mM})$. From these data, we conclude that the observed $\mathrm{H}_{2} \mathrm{O}_{2}$ protective effect is specifically dependent upon the presence of extracellular pyruvate secreted by the streptococci.

We also included the wild type of SK36 and its isogenic ccpA mutant in this assay. Low but significant amounts of pyruvate were detected, which increased due to the deletion of $c c p A$ (Fig. 7b).

\section{The protective phenotype is not limited to SK36 and DL1}

In addition to $S$. sanguinis SK36 and $S$. gordonii DL1, several other $s p x B$ mutants were generated (Fig. 7d). All $s p x B$-encoding species exhibited protection against $\mathrm{H}_{2} \mathrm{O}_{2}$ mediated killing, whereas the $s p x B^{-}$species $S$. mutans completely lacked this ability. Consistent with SK36 and DL1, the abundance of excreted pyruvate closely matched the pattern of $\mathrm{H}_{2} \mathrm{O}_{2}$ protection in all cases (Fig. 7e). Hence, 
A)

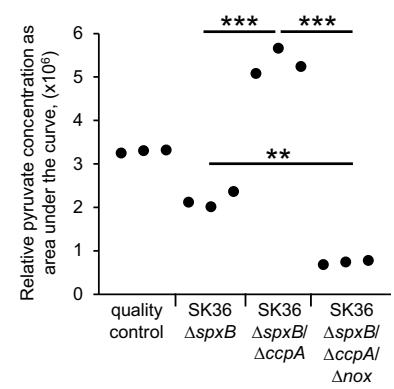

D)

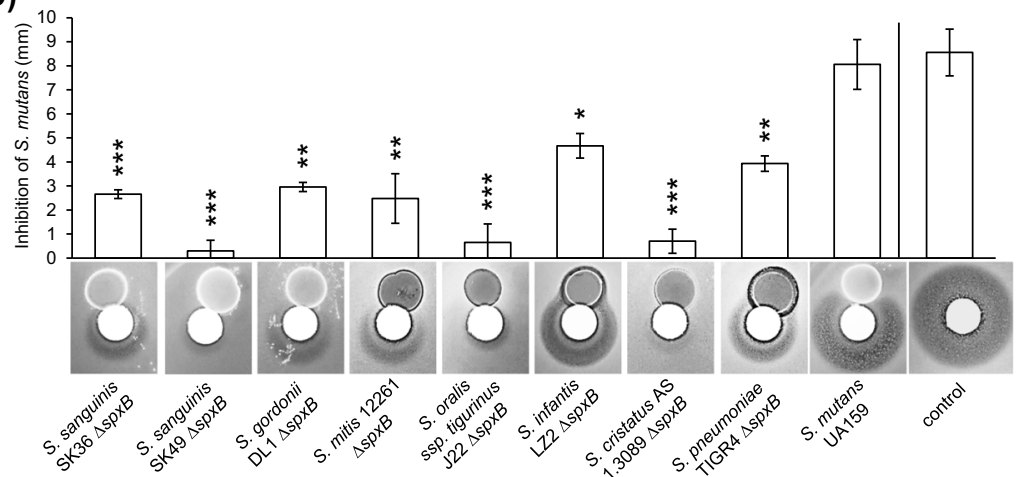

B)

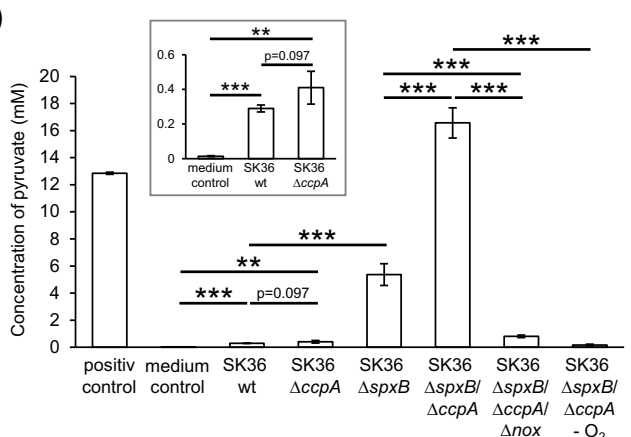

E)

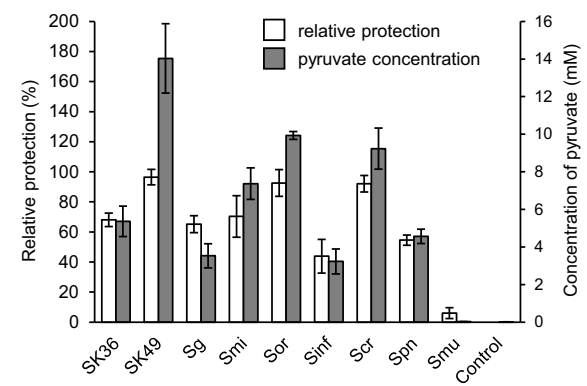

C)

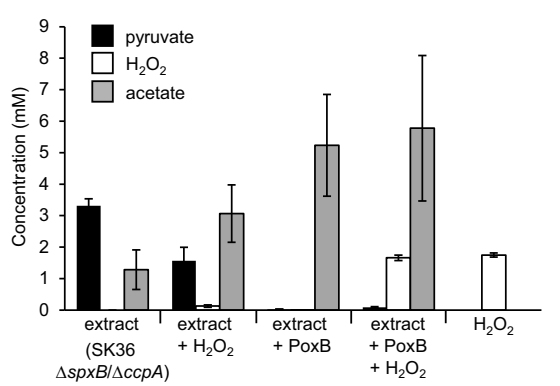

E)
Fig. 7 Pyruvate and $\mathrm{H}_{2} \mathrm{O}_{2}$ protection. a Relative amounts of pyruvate in the extracts of SK36 $\Delta s p x B$, SK36 $\Delta c c p A / \Delta s p x B$, and

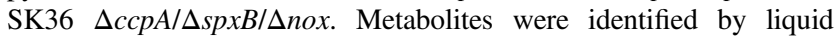
chromatography-information-dependent acquisition-mass spectrometry (LC-IDA-MS; Oregon State University Mass Spectrometry, Corvallis, OR, USA) using the IROA library of metabolite standards (IROA Technologies, Bolton, MA, USA). The integrated areas under the curve of extracted mass-to-charge-ratios $(\mathrm{m} / \mathrm{z})$ for pyruvate are shown. b Pyruvate concentrations were determined enzymatically in cell free extracts. Extracts were derived from aerobically grown SK36 wild-type strain, SK36 $\Delta c c p A$, SK36 $\Delta s p x B$, SK36 $\Delta c c p A / \Delta s p x B$, SK36 $\Delta c c p A / \Delta s p x B / \Delta$ nox, and anaerobically grown SK36 $\Delta c c p A /$ $\Delta \operatorname{spx} B\left(-\mathrm{O}_{2}\right)$. Extract from a $\mathrm{BHI}$ agar plate served as a negative control (BHI medium). A $10 \mathrm{mM}$ pyruvate solution served as positive control. A section of the graph is displayed with a different scale to highlight pyruvate concentrations of SK 36 wild-type and SK 36 ccpA mutant in comparison with the medium control. c Untreated and pyruvate depleted extracts of SK36 $\Delta c c p A / \Delta s p x B$ were tested in an $\mathrm{H}_{2} \mathrm{O}_{2}$ depletion assay $\left(2 \mathrm{mM} \mathrm{H}_{2} \mathrm{O}_{2}\right)$. Concentrations of pyruvate, $\mathrm{H}_{2} \mathrm{O}_{2}$, and acetate were determined enzymatically before and after the

the protective phenotype (mediated by excreted pyruvate) is not exclusively confined to $S$. sanguinis SK36 and $S$. gordonii DL1, rather this is likely a common characteristic of $\operatorname{spx} B^{+}$streptococci in general.

\section{Discussion}

\section{The new phenotype}

The release of $\mathrm{H}_{2} \mathrm{O}_{2}$ masked a previously unrecognized characteristic of $s p x B^{+}$streptococci: the ability to actively assay. ("extract"- untreated extracts before $\mathrm{H}_{2} \mathrm{O}_{2}$ depletion assay; "extract $+\mathrm{H}_{2} \mathrm{O}_{2}$ "- - untreated extracts after $\mathrm{H}_{2} \mathrm{O}_{2}$ depletion assay; "extract + PoxB" - pyruvate depleted extracts before $\mathrm{H}_{2} \mathrm{O}_{2}$ depletion assay; "extract + PoxB $+\mathrm{H}_{2} \mathrm{O}_{2}$ "-pyruvate depleted extracts after $\mathrm{H}_{2} \mathrm{O}_{2}$ depletion assay; " $\mathrm{H}_{2} \mathrm{O}_{2}$ " $-\mathrm{H}_{2} \mathrm{O}_{2}$ solution before $\mathrm{H}_{2} \mathrm{O}_{2}$ depletion assay). d $S$. mutans (not encoding spxB) and spxB deletion mutants of various streptococci were tested for their protective capacity with $\mathrm{H}_{2} \mathrm{O}_{2}$ protection assays. Paired $t$-tests (two-tailed) were performed testing each mutant against its respective $\mathrm{H}_{2} \mathrm{O}_{2}$ control. Note that the displayed control represents the average of all experiments. The averages and standard deviations of four independent experiments are shown with representative images. e The protective capacity of $S$. mutans and $s p x B$ mutants of various streptococci are shown together with the pyruvate concentrations of their respective extracts. The inhibition zones from Fig. 7D were transformed to "relative protection" for a better comparability $(0 \%=$ no protection $=$ full inhibition as it appears in the control; $100 \%=$ full protection (no inhibition zone visible)). All tested extracts were derived from three independent experiments. Significance levels: $* p<0.05 ; * * p<0.01 ; * * * p<0.001$ (two-tailed $t$-test, unpaired).

deplete $\mathrm{H}_{2} \mathrm{O}_{2}$ from the surrounding environment by the secretion of pyruvate.

Compared with their respective wild types, SK36 $\Delta c c p A$ and DL1 $\triangle c c p A$ demonstrated a decreased growth inhibition capacity against $\mathrm{H}_{2} \mathrm{O}_{2}$-susceptible $S$. mutans, while the release of $\mathrm{H}_{2} \mathrm{O}_{2}$ was not affected or even increased (detected by Prussian blue indicator plates, Fig. 1b). Here, we demonstrate that a significantly increased amount of pyruvate released into the environment (by the $c c p A$ mutant) is responsible for the scavenging of $\mathrm{H}_{2} \mathrm{O}_{2}$ (demonstrated in the $s p x B$ deletion background). Consequently, final $\mathrm{H}_{2} \mathrm{O}_{2}$ concentrations dropped to noninhibitory levels for the $е с p A$ 


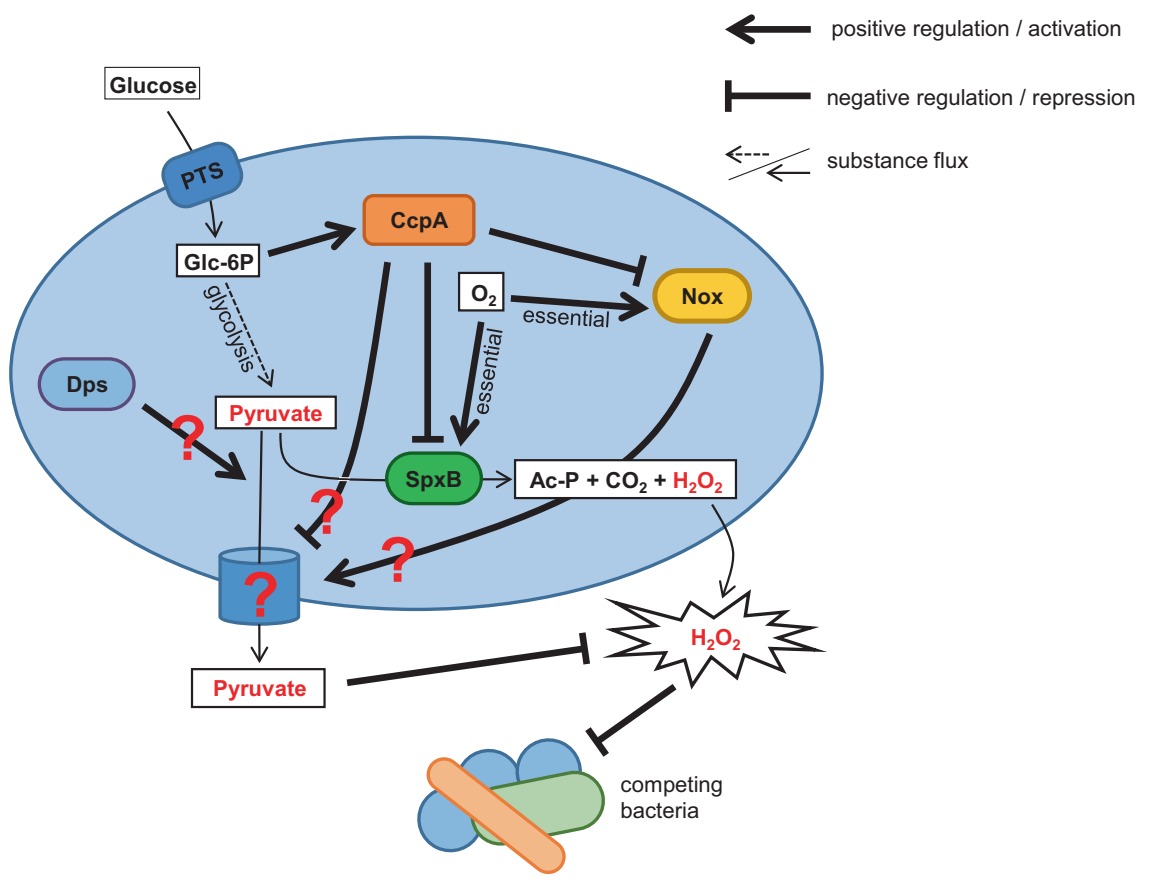

Fig. 8 Components modulating pyruvate release. Glycolysis provides the cell with energy and pyruvate, which can be exported by an unknown mechanism and function as a scavenger for extracellular $\mathrm{H}_{2} \mathrm{O}_{2}$. Pyruvate is also the substrate for $\mathrm{SpxB}$ and therefore needed for the generation of $\mathrm{H}_{2} \mathrm{O}_{2}$, acetyl-phosphate (Ac-P), and $\mathrm{CO}_{2}$. Extracellular glucose can be translocated through the cell membrane by the phosphotransferase system (PTS), which also phosphorylate glucose to glucose-6-phosphate (Glc-6P), which in turn can be metabolized through glycolysis. In addition, Glc-6P functions as a signal molecule for the presence of glucose and initializes catabolite repression through

deletion mutants (as indicated in Fig. 1a, plain BHI, without Prussian blue indicator), which exhibit increased pyruvate production. Supporting this assumption, the pyruvate release in the cсpA deletion mutant of SK36 was elevated compared with the parental wild-type strain, albeit not significant (Fig. 7b).

A $\mathrm{H}_{2} \mathrm{O}_{2}$ dependent self-inhibitory effect could also explain our observation, by an increased amount of $\mathrm{H}_{2} \mathrm{O}_{2}$ inhibiting the growth of the ccpA deletion mutant itself and thus resulting in an overall reduction of the final $\mathrm{H}_{2} \mathrm{O}_{2}$ concentration. However, since there is no significant increased $\mathrm{H}_{2} \mathrm{O}_{2}$ release in DL1 $\Delta c c p A$, which could trigger such a self-inhibitory effect, it might only play a minor role under the given conditions.

\section{The role of Dps and Nox}

Transposon mutagenesis and targeted gene deletions identified $d p s$ and nox as associated with the protective phenotype. Dps is a ferritin-like protein that mediates resistance to $\mathrm{H}_{2} \mathrm{O}_{2}$ by chelating iron and binding DNA, thus preventing Fenton-mediated killing mechanisms [14, 17, 43]. Since the protective effect is the result of pyruvate excreted into the the CcpA pathway. Activated CcpA represses transcription of $s p x B$, nox, and other genes (not shown), and thus influences $\mathrm{H}_{2} \mathrm{O}_{2}$ as well as pyruvate release. Nox is an oxygen dependent NADH oxidase, which is also involved in pyruvate release by an unknown mechanism. Dps also alters the release on pyruvate by an unknown pathway. Potential mechanisms are discussed in the text. $\mathrm{H}_{2} \mathrm{O}_{2}$ generation via $\mathrm{SpxB}$ as well as pyruvate release depends on the presence of oxygen. Ac-P acetyl phosphate, Glc-6P glucose-6-phosphate, PTS phosphotransferase system.

environment, the intracellular protein Dps is unlikely to be directly involved in the protection process. Thus, we speculate there is a potential regulatory function for Dps, possibly through its predicted DNA binding ability. Alternatively, the deletion of Dps might increase intracellular iron levels, which in turn decrease the intracellular concentration of pyruvate due to a possible reaction of both compounds [44]. As a result, less pyruvate would be available for secretion as depicted in the overview figure of the here presented regulatory factors and substances influencing $\mathrm{H}_{2} \mathrm{O}_{2}$ and pyruvate release (Fig. 8).

The NADH Oxidase Nox seems to play an essential role in the protective phenotype, as evident from the inability of the nox mutant to confer protection. Interestingly, the secretion of pyruvate as well as the $\mathrm{H}_{2} \mathrm{O}$-forming activity of Nox are both oxygen-dependent processes (Fig. 4c) $[45,46]$. In addition, nox expression is under the control of CcpA (http://regprecise.lbl.gov [41, 47, 48]), which might explain the CcpA dependency of the protective phenotype. Although the activity of Nox is critical for the protective effect, NADH oxidase is also present in other streptococci like $S$. mutans $(81 \%$ identity on amino acid level compared with SK36), which did not exhibit any detectable protective 
activity or pyruvate secretion. Furthermore, it is presently unclear how Nox stimulates pyruvate secretion. Nox is an oxygen dependent NADH oxidase and therefore involved in the regeneration of $\mathrm{NADH}$ to $\mathrm{NAD}^{+}$, important for an undisrupted glycolysis [49] and thus for the generation of pyruvate. The lack of $\mathrm{NAD}^{+}$would affect growth dramatically, but we did not observe any growth deficiencies comparing oxic and anoxic growth, neither in the wild-type background nor in the $\operatorname{sp} x B$ deletion mutant. This might be explained by alternative metabolic pathways to regenerate $\mathrm{NAD}^{+}$via lactate dehydrogenase or formation of ethanol [50]. Thus, pyruvate secretion could also be influenced by the disrupted SpxB pathway. This would also explain why the effect is limited to $s p x B^{+}$species, since they prefer the more beneficial pathway (one more ATP per pyruvate). Other species are limited to lactate or ethanol formation and might therefore do not secrete pyruvate.

The activity of Nox also affects the intracellular redox potential through the $\mathrm{NAD}^{+} / \mathrm{NADH}-$ ratio. Therefore, the loss of Nox alters expression of genes involved in energy metabolism, transport, several genes encoding transcription factors, and signaling molecules [51-53]. Thus, we speculate that Nox modulates pyruvate release by affecting activity or expression of other factors that are needed for the release of pyruvate.

\section{Pyruvate release and the newly identified protective effect of $s p x B$ positive streptococci}

Pyruvate is a critical central intermediate of cellular metabolism and is involved in energy generation, amino acid biosynthesis, and acid tolerance [29, 54-56]. Strikingly, pyruvate is also the substrate for the pyruvate oxidase $\mathrm{SpxB}$ and therefore directly involved in the production of $\mathrm{H}_{2} \mathrm{O}_{2}$ [29] (Fig. 8). As a potent $\mathrm{H}_{2} \mathrm{O}_{2}$ scavenger, pyruvate has been reported to protect neurons and other eukaryotic cells from $\mathrm{H}_{2} \mathrm{O}_{2}$ toxicity [57-59]. Recent studies demonstrated that microorganisms also utilize pyruvate to detoxify intracellular $\mathrm{H}_{2} \mathrm{O}_{2}$ or can benefit from host derived pyruvate to passively escape the human immune response [60-62]. Here, we describe the first prokaryotic example of an active pyruvate secretion to mitigate the deleterious effects of $\mathrm{H}_{2} \mathrm{O}_{2}$. Hence, pyruvate secretion has the potential to extend the streptococcal toolbox for the management of reactive oxygen species stress and might be an important component that aides in direct $\mathrm{H}_{2} \mathrm{O}_{2}$ detoxification [14, 17, 37-40, 63].

Our knowledge of the biological relevance of the here described pyruvate secretion phenotype is limited at this time. We could demonstrate that $S$. sanguinis wild type is secreting detectable amounts of pyruvate under conditions that are highly selective for optimized $\mathrm{H}_{2} \mathrm{O}_{2}$ production. This suggests that not all pyruvate is reacting with the $\mathrm{H}_{2} \mathrm{O}_{2}$ produced by the wild type, potentially being able to serve as antioxidant for nearby species. However, this speculation requires further validation for example with a genetically controlled release of pyruvate. Efforts are currently underway to identify the respective pyruvate secretion mechanism in oral streptococci to address the biological relevance in the context of the oral biofilm. Of note, naturally occurring $\operatorname{sp} x B$ mutants were described for the typically $s p x B^{+}$species $S$. pneumoniae. The tested mutants were more virulent compared with their $\mathrm{SpxB}$ expressing (and $\mathrm{H}_{2} \mathrm{O}_{2}$ releasing) counterparts [64-66]. As demonstrated in the present study, the mutation of $\operatorname{sp} x B$ and thus the reduced release of $\mathrm{H}_{2} \mathrm{O}_{2}$ results in an elevated pyruvate release, which in turn could be related to the increased virulence level. Therefore, future investigations targeting the in vivo meaning of the here described effect will have to focus also on naturally occurring $s p x B$ mutants, since there are no data available regarding their abundancy.

Pyruvate transport has been characterized as an inwardly directed energy-dependent process [67]. A recent study identified a member of the peptide transporter carbon starvation (CstA) family as a specific pyruvate/ $\mathrm{H}+$ symporter in $E$. coli $[68,69]$. Nevertheless, no obvious homologous SK36 proteins could be identified for any of the known pyruvate transporters (CstA, BtsT from E. coli [68, 69], MPC1 and MPC2 known as mitochondrial pyruvate carrier [70], or MctC from Corynebacterium glutamicum [71]). However, another recent study suggests a novel class of transporters as involved in the passive transport of pyruvate in $S$. mutans via the $\operatorname{lrg} A B$ system, which had been previously described as a holin/antiholin system in Bacillus subtilis and Staphylococcus aureus [72-74]. We examined the respective $\operatorname{lrgAB}$ orthologs in SK36 (SSA_0842 and SSA_0843) as well as the LrgAB-associated two-component system lytST (SSA_1119 and SSA_1120) [72, 73] and observed no connection to the secretion of pyruvate (data not shown). Hence, it is still unclear how the cells manage to release pyruvate. The fact that no transporter could be identified via transposon mutagenesis suggests that the respective transporter is either essential or there are redundant pyruvate transporters.

\section{Implications for the development and maturation of mixed-species oral biofilms}

The ability to release $\mathrm{H}_{2} \mathrm{O}_{2}$ is recognized a key mechanism for streptococcal interspecies antagonism during oral biofilm development $[11,20,21]$. Abundant $\mathrm{SpxB}^{+}$streptococci inhibit susceptible bacteria by the secretion of growth inhibiting amounts of $\mathrm{H}_{2} \mathrm{O}_{2}$, which generates highly reactive hydroxyl radicals intracellularly via the Fenton reaction triggering irreparable DNA damage [75]. In SK36 and DL1, spxB expression and $\mathrm{H}_{2} \mathrm{O}_{2}$ release are controlled by CcpA $[24,25,33]$, the primary carbon catabolite regulator in 
Gram-positive bacteria. CcpA regulates the cellular response to the availability of carbohydrates [76]. Remarkably, the response to an elevated amount of glucose is different in both species: while SK36 does not alter the release of $\mathrm{H}_{2} \mathrm{O}_{2}$ [21, 33], DL1 releases significantly less $\mathrm{H}_{2} \mathrm{O}_{2}$ in the presence of high-glucose concentrations $[25,33]$. The $\mathrm{H}_{2} \mathrm{O}_{2}$ protective phenotype is also under the control of CcpA and follows the same pattern both species. For example, in DL1 both $\mathrm{H}_{2} \mathrm{O}_{2}$ release and the protective effect follow classical catabolite repression, while in SK36 only the protective effect is subject to catabolite control whereas $s p x B$ expression seems to be under permanent CcpA repression [21, 33]. This observation suggests additional regulatory mechanisms likely exist to modulate these antagonistic systems of $\mathrm{H}_{2} \mathrm{O}_{2}$ homeostasis. Remarkably, the $\mathrm{H}_{2} \mathrm{O}_{2}$ protective ability seems to be present in most or all $s p x B^{+}$streptococci, including low-passage clinical isolates as well as the human pathogen $S$. pneumoniae. Thus, this ability might impact many different microbiome communities outside of the oral cavity, as oral streptococci are frequently found in the nasopharynx and respiratory tract, while $\operatorname{spx} B^{+}$streptococci (especially S. pneumoniae) are also associated with severe invasive infections [77-81].

\section{Pyruvate secretion and the immune response}

Several recent studies have revealed additional functions of $\mathrm{H}_{2} \mathrm{O}_{2}$. It has been demonstrated to serve as an effective signal molecule for the immune response and is also as a key player in the genesis of lung carcinoma [82-85]. Hence, the ability of bacteria to modulate the level of external $\mathrm{H}_{2} \mathrm{O}_{2}$ could have a much broader impact and might not be limited to interspecies competition among the microbiome. Since the ability to modulate the level of $\mathrm{H}_{2} \mathrm{O}_{2}$ seems to be present in $\operatorname{spxB}^{+}$commensals as well as in some pathogenic streptococci, it will be interesting to determine whether these organisms are potentially able to actively influence the host immune response through the modulation of $\mathrm{H}_{2} \mathrm{O}_{2}$ availability.

\section{Limitations of the study}

The here described experiments focus on a protective compound being effective against a range of $20-100 \mathrm{mM}$ $\mathrm{H}_{2} \mathrm{O}_{2}$. This range was selected to optimally display the protective effect on the tested mutants. Moreover, $\mathrm{H}_{2} \mathrm{O}_{2}$ generation and pyruvate release were measured under ideal laboratory conditions (optimal aeration) and do not necessarily mimic the actual physiological environment. $\mathrm{H}_{2} \mathrm{O}_{2}$ concentrations under laboratory conditions have been shown to reach up to $1.6 \mathrm{mM}$ in single-species biofilms of $S$. gordonii [86] depending on growth conditions, time period, and method of measurement. The transient concentration in saliva has been calculated to be around $10 \mu \mathrm{M}$ based on known concentrations of thiocyanate and hypothiocyanite in saliva [12], but no data is available for actual oral biofilms in situ. Furthermore, in this study we focused on $s p x B$ mutants and its derivatives, since wild-type strains as well as isogenic ccpA mutants produce significant amounts of $\mathrm{H}_{2} \mathrm{O}_{2}$, which masked the protective effect making it difficult to present. Nevertheless, a significant amount of released pyruvate was detectable for $S$. sanguinis (Fig. $7 b$ ). Therefore, the ecological meaning of active pyruvate secretion regarding $\mathrm{H}_{2} \mathrm{O}_{2}$ homeostasis needs further investigation.

Acknowledgements The authors would like to acknowledge the following National Institutes of Health grants: R56-DE021726 (JK), R35DE028252 (JM). The project described was supported, in part by the Oregon State University Research Office. The content is solely the responsibility of the authors and does not necessarily represent the official views of the OSU Mass Spectrometry Center. The authors acknowledge the OSU Mass Spectrometry Center at Oregon State University and specific institutional instrument grants. Orbitrap Fusion Lumos-NIH \# 1S10OD020111-01, Waters Ion Mobility ToF Mass Spectrometer-NIH \#1S10RR025628-01, Applied Biosystems 4000Qtrap-NIH \# 1S10RR022589-01, ABSciex Triple ToF 5600NIH \#1S10RR027878-01.

\section{Compliance with ethical standards}

Conflict of interest The authors declare that they have no conflict of interest.

Publisher's note Springer Nature remains neutral with regard to jurisdictional claims in published maps and institutional affiliations.

\section{References}

1. Dewhirst FE, Chen T, Izard J, Paster BJ, Tanner AC, Yu WH, et al. The human oral microbiome. J Bacteriol. 2010;192:5002-17.

2. Jefferson KK. What drives bacteria to produce a biofilm? FEMS Microbiol Lett. 2004;236:163-73.

3. Huang R, Li M, Gregory RL. Bacterial interactions in dental biofilm. Virulence. 2011;2:435-44.

4. Roberts FA, Darveau RP. Beneficial bacteria of the periodontium. Periodontology 2000. 2002;30:40-50.

5. Avila M, Ojcius DM, Yilmaz O. The oral microbiota: living with a permanent guest. DNA Cell Biol. 2009;28:405-11.

6. Asikainen S, Alaluusua S. Bacteriology of dental infections. Eur Heart J. 1993;14:43-50.

7. Li X, Kolltveit KM, Tronstad L, Olsen I. Systemic diseases caused by oral infection. Clin Microbiol Rev. 2000;13:547-58.

8. Rosan B, Lamont RJ. Dental plaque formation. Microbes Infect. 2000;2:1599-607.

9. Chen L, Ge X, Dou Y, Wang X, Patel JR, Xu P. Identification of hydrogen peroxide production-related genes in Streptococcus sanguinis and their functional relationship with pyruvate oxidase. Microbiology 2011;157:13-20.

10. Velsko IM, Chakraborty B, Nascimento MM, Burne RA, Richards VP. Species designations belie phenotypic and genotypic heterogeneity in oral streptococci. mSystems. 2018;3:e00158-18.

11. Redanz S, Cheng X, Giacaman RA, Pfeifer CS, Merritt J, Kreth J. Live and let die: hydrogen peroxide production by the commensal 
flora and its role in maintaining a symbiotic microbiome. Mol Oral Microbiol. 2018;33:337-52.

12. Zhu L, Kreth J. The role of hydrogen peroxide in environmental adaptation of oral microbial communities. Oxid Med Cell Longev. 2012;2012:717843.

13. Zheng LY, Itzek A, Chen ZY, Kreth J. Oxygen dependent pyruvate oxidase expression and production in Streptococcus sanguinis. Int J Oral Sci. 2011;3:82-9.

14. Fujishima K, Kawada-Matsuo M, Oogai Y, Tokuda M, Torii M, Komatsuzawa H. dpr and sod in Streptococcus mutans are involved in coexistence with $S$. sanguinis, and PerR is associated with resistance to $\mathrm{H}_{2} \mathrm{O}_{2}$. Appl Environ Microbiol. 2013;79:1436-43.

15. Pericone CD, Park S, Imlay JA, Weiser JN. Factors contributing to hydrogen peroxide resistance in Streptococcus pneumoniae include pyruvate oxidase $(\mathrm{SpxB})$ and avoidance of the toxic effects of the fenton reaction. J Bacteriol. 2003;185:6815-25.

16. Lei Y, Zhang Y, Guenther BD, Kreth J, Herzberg MC. Mechanism of adhesion maintenance by methionine sulphoxide reductase in Streptococcus gordonii. Mol Microbiol. 2011;80:726-38.

17. Xu Y, Itzek A, Kreth J. Comparison of genes required for $\mathrm{H}_{2} \mathrm{O}_{2}$ resistance in Streptococcus gordonii and Streptococcus sanguinis. Microbiology. 2014;160:2627-38.

18. Xu P, Alves JM, Kitten T, Brown A, Chen Z, Ozaki LS, et al. Genome of the opportunistic pathogen Streptococcus sanguinis. J Bacteriol. 2007;189:3166-75.

19. Engelmann S, Hecker M. Impaired oxidative stress resistance of Bacillus subtilis $\operatorname{sig} B$ mutants and the role of katA and katE. FEMS Microbiol Lett. 1996;145:63-9.

20. Kreth J, Zhang Y, Herzberg MC. Streptococcal antagonism in oral biofilms: Streptococcus sanguinis and Streptococcus gordonii interference with Streptococcus mutans. J Bacteriol. 2008;190:4632-40.

21. Kreth J, Merritt J, Shi W, Qi F. Competition and coexistence between Streptococcus mutans and Streptococcus sanguinis in the dental biofilm. J Bacteriol. 2005;187:7193-203.

22. Lemos JA, Quivey RG Jr, Koo H, Abranches J. Streptococcus mutans: a new Gram-positive paradigm? Microbiology. 2013;159:436-45.

23. Krzysciak W, Jurczak A, Koscielniak D, Bystrowska B, Skalniak A. The virulence of Streptococcus mutans and the ability to form biofilms. Eur J Clin Microbiol Infect Dis. 2014;33:499-515.

24. Zheng L, Chen Z, Itzek A, Ashby M, Kreth J. Catabolite control protein A controls hydrogen peroxide production and cell death in Streptococcus sanguinis. J Bacteriol. 2011;193:516-26.

25. Zheng L, Itzek A, Chen Z, Kreth J. Environmental influences on competitive hydrogen peroxide production in Streptococcus gordonii. Appl Environ Microbiol. 2011;77:4318-28.

26. Hobley L, Harkins C, MacPhee CE, Stanley-Wall NR. Giving structure to the biofilm matrix: an overview of individual strategies and emerging common themes. FEMS Microbiol Rev. 2015;39:649-69.

27. Sambrook J, Fritsch EF, Maniatis T. Molecular cloning: a laboratory manual. 2nd ed: NY: Cold Spring Harbor Laboratory, Cold Spring Harbor; 1989.

28. Zhu L, Zhang Y, Fan J, Herzberg MC, Kreth J. Characterization of competence and biofilm development of a Streptococcus sanguinis endocarditis isolate. Mol Oral Microbiol. 2011;26:117-26.

29. Cheng X, Redanz S, Cullin N, Zhou X, Xu X, Joshi V, et al. Plasticity of the pyruvate node modulates hydrogen peroxide production and acid tolerance in multiple oral streptococci. Appl Environ Microbiol. 2018;84:e01697-17.

30. Redanz S, Standar K, Podbielski A, Kreikemeyer B. Heterologous expression of $s a h H$ reveals that biofilm formation is autoinducer2-independent in Streptococcus sanguinis but is associated with an intact activated methionine cycle. J Biol Chem. 2012;287:36111-22.
31. Johnsborg O, Blomquist T, Kilian, M, Håvarstein, L.S. Biologically active peptides in streptococci. In: Molecular biology of streptococci. Hakenbeck R, Chhatwal S, editors. Norwich: Horizon Scientific Press. 2007:p. 42-7.

32. Saito M, Seki M, Iida K, Nakayama H, Yoshida S. A novel agar medium to detect hydrogen peroxide-producing bacteria based on the prussian blue-forming reaction. Microbiol Immunol. 2007;51:889-92.

33. Redanz S, Masilamani R, Cullin N, Giacaman RA, Merritt J, Kreth J. Distinct regulatory role of carbon catabolite protein A (CcpA) in oral Streptococcal spxB expression. J Bacteriol. 2018;200:e00619-17.

34. van Opijnen T, Lazinski DW, Camilli A. Genome-wide fitness and genetic interactions determined by Tn-seq, a high-throughput massively parallel sequencing method for microorganisms. Curr Protoc Microbiol. 2015;36:1E 3 1-24.

35. Tan G, Gao Y, Shi M, Zhang X, He S, Chen Z, et al. SiteFindingPCR: a simple and efficient PCR method for chromosome walking. Nucleic Acids Res. 2005;33:e122.

36. Zhu A, Romero R, Petty HR. A sensitive fluorimetric assay for pyruvate. Anal Biochem. 2010;396:146-51.

37. Lushchak VI. Glutathione homeostasis and functions: potential targets for medical interventions. $\mathrm{J}$ Amino Acids. 2012;2012:736837.

38. Zheng X, Zhang K, Zhou X, Liu C, Li M, Li Y, et al. Involvement of $g \operatorname{sh} A B$ in the interspecies competition within oral biofilm. $\mathrm{J}$ Dent Res. 2013;92:819-24.

39. Owens RA, Hartman PE. Export of glutathione by some widely used Salmonella typhimurium and Escherichia coli strains. J Bacteriol. 1986;168:109-14.

40. Wang X, Tong H, Dong X. PerR-regulated manganese ion uptake contributes to oxidative stress defense in an oral streptococcus. Appl Environ Microbiol. 2014;80:2351-9.

41. Novichkov PS, Kazakov AE, Ravcheev DA, Leyn SA, Kovaleva GY, Sutormin RA, et al. RegPrecise 3.0 - a resource for genomescale exploration of transcriptional regulation in bacteria. BMC Genom. 2013;14:745.

42. Xu P, Ge X, Chen L, Wang X, Dou Y, Xu JZ, et al. Genome-wide essential gene identification in Streptococcus sanguinis. Sci Rep. 2011;1:125.

43. Calhoun LN, Kwon YM. Structure, function and regulation of the DNA-binding protein Dps and its role in acid and oxidative stress resistance in Escherichia coli: a review. J Appl Microbiol. 2011;110:375-86.

44. Muchowska KB, Varma SJ, Moran J. Synthesis and breakdown of universal metabolic precursors promoted by iron. Nature. 2019;569:104-7.

45. Ge X, Yu Y, Zhang M, Chen L, Chen W, Elrami F, et al. Involvement of NADH oxidase in competition and endocarditis virulence in Streptococcus sanguinis. Infect Immun. 2016;84:1470-7.

46. Carvalho SM, Farshchi Andisi V, Gradstedt H, Neef J, Kuipers OP, Neves AR, et al. Pyruvate oxidase influences the sugar utilization pattern and capsule production in Streptococcus pneumoniae. PloS one 2013;8:e68277.

47. Novichkov PS, Brettin TS, Novichkova ES, Dehal PS, Arkin AP, Dubchak I, et al. RegPrecise web services interface: programmatic access to the transcriptional regulatory interactions in bacteria reconstructed by comparative genomics. Nucleic Acids Res. 2012;40:W604-8.

48. Novichkov PS, Laikova ON, Novichkova ES, Gelfand MS, Arkin AP, Dubchak I, et al. RegPrecise: a database of curated genomic inferences of transcriptional regulatory interactions in prokaryotes. Nucleic Acids Res 2010;38:D111-8.

49. Higuchi M, Yamamoto Y, Poole LB, Shimada M, Sato Y, Takahashi N, et al. Functions of two types of NADH oxidases in 
energy metabolism and oxidative stress of Streptococcus mutans. J Bacteriol. 1999;181:5940-7.

50. Carvalho SM, Kuipers OP, Neves AR. Environmental and nutritional factors that affect growth and metabolism of the pneumococcal serotype 2 strain D39 and its nonencapsulated derivative strain R6. PLoS One 2013;8:e58492.

51. Afzal M, Shafeeq S, Kuipers OP. NADH-Mediated Gene Expression in Streptococcus pneumoniae and Role of Rex as a Transcriptional Repressor of the Rex-Regulon. Front Microbiol. 2018;9:1300.

52. Baker JL, Derr AM, Karuppaiah K, MacGilvray ME, Kajfasz JK, Faustoferri RC, et al. Streptococcus mutans NADH oxidase lies at the intersection of overlapping regulons controlled by oxygen and NAD+ levels. J Bacteriol. 2014;196:2166-77.

53. Zheng C, Ren S, Xu J, Zhao X, Shi G, Wu J, et al. Contribution of NADH oxidase to oxidative stress tolerance and virulence of Streptococcus suis serotype 2. Virulence. 2017;8:53-65.

54. Deibel RH, Niven CF Jr. Pyruvate fermentation by Streptococcus faecalis. J Bacteriol. 1964;88:4-10.

55. Su YB, Peng B, Li H, Cheng ZX, Zhang TT, Zhu JX, et al. Pyruvate cycle increases aminoglycoside efficacy and provides respiratory energy in bacteria. Proc Natl Acad Sci USA. 2018;115: E1578-E87.

56. Hartel T, Eylert E, Schulz C, Petruschka L, Gierok P, Grubmuller $\mathrm{S}$, et al. Characterization of central carbon metabolism of Streptococcus pneumoniae by isotopologue profiling. J Biol Chem. 2012;287:4260-74.

57. Desagher S, Glowinski J, Premont J. Pyruvate protects neurons against hydrogen peroxide-induced toxicity. J Neurosci. 1997;17:9060-7.

58. Wang X, Perez E, Liu R, Yan LJ, Mallet RT, Yang SH. Pyruvate protects mitochondria from oxidative stress in human neuroblastoma SK-N-SH cells. Brain Res. 2007;1132:1-9.

59. Long LH, Halliwell B. Artefacts in cell culture: pyruvate as a scavenger of hydrogen peroxide generated by ascorbate or epigallocatechin gallate in cell culture media. Biochem Biophys Res Commun. 2009;388:700-4.

60. van Niel EW, Hofvendahl K, Hahn-Hagerdal B. Formation and conversion of oxygen metabolites by Lactococcus lactis subsp. lactis ATCC 19435 under different growth conditions. Appl Environ Microbiol. 2002;68:4350-6.

61. Kim JG, Park SJ, Sinninghe Damste JS, Schouten S, Rijpstra WI, Jung MY, et al. Hydrogen peroxide detoxification is a key mechanism for growth of ammonia-oxidizing archaea. Proc Natl Acad Sci USA. 2016;113:7888-93.

62. Troxell B, Zhang JJ, Bourret TJ, Zeng MY, Blum J, Gherardini F, et al. Pyruvate protects pathogenic spirochetes from $\mathrm{H}_{2} \mathrm{O}_{2}$ killing. PloS One. 2014;9:e84625.

63. Mishra S, Imlay J. Why do bacteria use so many enzymes to scavenge hydrogen peroxide? Arch Biochem Biophys. 2012;525:145-60.

64. Bryant JC, Dabbs RC, Oswalt KL, Brown LR, Rosch JW, Seo $\mathrm{KS}$, et al. Pyruvate oxidase of Streptococcus pneumoniae contributes to pneumolysin release. BMC Microbiol. 2016;16:271.

65. Pericone CD, Overweg K, Hermans PW, Weiser JN. Inhibitory and bactericidal effects of hydrogen peroxide production by Streptococcus pneumoniae on other inhabitants of the upper respiratory tract. Infect Immun. 2000;68:3990-7.

66. Spellerberg B, Cundell DR, Sandros J, Pearce BJ, IdanpaanHeikkila I, Rosenow C, et al. Pyruvate oxidase, as a determinant of virulence in Streptococcus pneumoniae. Mol Microbiol. 1996;19:803-13.
67. Lang VJ, Leystra-Lantz C, Cook RA. Characterization of the specific pyruvate transport system in Escherichia coli K-12. J Bacteriol. 1987;169:380-5.

68. Kristoficova I, Vilhena C, Behr S, Jung K. BtsT, a novel and specific pyruvate/ $\mathrm{H}(+)$ symporter in Escherichia coli. J Bacteriol. 2018;200:e00599-17.

69. Hwang S, Choe D, Yoo M, Cho S, Kim SC, Cho S, et al. Peptide transporter CstA imports pyruvate in Escherichia coli $\mathrm{K}-12$. J Bacteriol. 2018;200:e00771-17.

70. McCommis KS, Finck BN. Mitochondrial pyruvate transport: a historical perspective and future research directions. Biochem $\mathrm{J}$. 2015;466:443-54.

71. Jolkver E, Emer D, Ballan S, Kramer R, Eikmanns BJ, Marin K. Identification and characterization of a bacterial transport system for the uptake of pyruvate, propionate, and acetate in Corynebacterium glutamicum. J Bacteriol 2009;191:940-8.

72. Charbonnier T, Le Coq D, McGovern S, Calabre M, Delumeau O, Aymerich S, et al. Molecular and physiological logics of the pyruvate-induced response of a novel transporter in Bacillus subtilis. mBio. 2017;8:e00976-17.

73. Sadykov MR, Bayles KW. The control of death and lysis in staphylococcal biofilms: a coordination of physiological signals. Curr Opin Microbiol. 2012;15:211-5.

74. Ahn SJ, Deep K, Turner ME, Ishkov I, Waters A, Hagen SJ, et al. Characterization of $\operatorname{Lrg} \mathrm{AB}$ as a stationary phase-specific pyruvate uptake system in Streptococcus mutans. BMC Microbiol 2019;19:223.

75. Winterbourn CC. Toxicity of iron and hydrogen peroxide: the Fenton reaction. Toxicol Lett. 1995;82-83:969-74.

76. Deutscher J. The mechanisms of carbon catabolite repression in bacteria. Curr Opin Microbiol. 2008;11:87-93.

77. Seppala H, Haanpera M, Al-Juhaish M, Jarvinen H, Jalava J, Huovinen P. Antimicrobial susceptibility patterns and macrolide resistance genes of viridans group streptococci from normal flora. J Antimicrob Chemother. 2003;52:636-44.

78. Siegel SJ, Weiser JN. Mechanisms of bacterial colonization of the respiratory tract. Annu Rev Microbiol. 2015;69:425-44.

79. Cahill TJ, Prendergast BD. Infective endocarditis. Lancet. 2016;387:882-93.

80. Liu YT, Lin CF, Lee YL. Streptococcus sanguinis meningitis following endoscopic ligation for oesophageal variceal haemorrhage. J Med Microbiol. 2013;62:794-6.

81. O'Brien KL, Wolfson LJ, Watt JP, Henkle E, Deloria-Knoll M, McCall N, et al. Burden of disease caused by Streptococcus pneumoniae in children younger than 5 years: global estimates. Lancet. 2009;374:893-902.

82. Wittmann C, Chockley P, Singh SK, Pase L, Lieschke GJ, Grabher C. Hydrogen peroxide in inflammation: messenger, guide, and assassin. Adv Hematol. 2012;2012:541471.

83. Gough DR, Cotter TG. Hydrogen peroxide: a Jekyll and Hyde signalling molecule. Cell Death Dis. 2011;2:e213.

84. Di Marzo N, Chisci E, Giovannoni R. The role of hydrogen peroxide in redox-dependent signaling: homeostatic and pathological responses in mammalian cells. Cells. 2018;7: E156.

85. Upadhyay S, Vaish S, Dhiman M. Hydrogen peroxide-induced oxidative stress and its impact on innate immune responses in lung carcinoma A549 cells. Mol Cell Biochem. 2019;450:135-47.

86. Liu X, Ramsey MM, Chen X, Koley D, Whiteley M, Bard AJ. Realtime mapping of a hydrogen peroxide concentration profile across a polymicrobial bacterial biofilm using scanning electrochemical microscopy. Proc Natl Acad Sci USA. 2011;108:2668-73. 